\title{
EXTENDING THE CONCEPT OF CITY FOR THE DELINEATION OF LARGE URBAN REGIONS (LUR) FOR THE CITIES OF THE WORLD
}

\author{
Céline Rozenblat, University of Lausanne, Celine.rozenblat@unil.ch
}

\begin{abstract}
Cities' delineation remains a hot topic of debate in a time where comparisons between cities are becoming increasingly based on different issues that address various scales of interventions and thus different concepts of cities. Aiming to compare cities and their insertion into globalization, we suggest that the "urban field of influence" is the best way to approach cities for this specific perspective. However, after reviewing the different existing possible concepts, we replace this concept with four different approaches proposed by Pumain et al. (1992): political entities, morphological agglomerations, functional urban areas and conurbations/Mega city regions. We discuss the top-down and bottom-up existing initiatives launched at the world scale and then use a mixed top-down and bottom-up approach to propose a new delineation of a large urban region (LUR), denoting a concept close to the conurbation or Mega city-region concept. The compositions of these LURs are published as an initial incomplete framework, suggesting the need for further critical comments and contributions to improve them.
\end{abstract}

\section{Keywords}

Cities, definition, Megalopolis, Large Urban Regions, Functional Urban regions, Urban agglomerations, world, statistical delineation, comparative urban research

\section{Introduction}

The issue of defining cities worldwide in a comparative way recently emerged with the visible growth of the urban population (reaching more than half of the world's population in the 2000s, UN Habitat, 2016) and the increasing global insertion of cities. It has been accompanied by the awareness of the need to better manage social, economic and environmental contexts to achieve more urban resilience (Rogov \& Rozenblat, 2018) and by a resurgence of the systems of cities approaches (Rozenblat \& Pumain, 2018); these approaches have filled the gap caused by the over-investigation through local case studies that avoid city comparisons and cannot permit general contextualized recommendations. Comparing cities must allow each of them to build adapted policies in a relevant urban perimeter. This perimeter depends on the characteristics of the city's spatial surroundings, but also on its national and regional contexts of economic, social and institutional development.

The choice of a general definition of cities among multiple possibilities is strongly influenced by the focused questions and goals of the world cities' comparisons (Pumain et al., 1992; Parr, 2007; Batty, 2018). For example, in the perspective of modeling cities and the dynamics of networks in a multilevel system approach from 
local to global, the adoption of a very extended acceptation of the city is needed. In fact, the impacts of globalization concern large areas around each core or groups of core cities, both in terms of economic attractiveness and spillovers, as well as local social networking and regional ecological impacts.

Considering this perspective, the definition we adopted is based on the concept of large urban regions (LURs) subdivided into three other nested levels of delineations; this definition should not only enable making acceptable comparisons all over the world, but also permit conducting comparative approaches at different continental or national geographical scales. "Top-down" systematic approaches are now developed at the world scale according to satellite images, whereas "bottom-up" approaches (such as those followed by the UN since 1948) gather national delineations to consider the territorial specificities in terms of geography, history and institutions. With LURs, we propose a mixed bottom-up/top-down approach, applying similar rules based on national delineations. Although countries implement their cities' delineations in different ways, each level of delineation we have defined follows the same conceptual idea, which was adapted to each national or continental historical and political context and was dependent on the availability of data. In this way, we argue that despite a variety of implementations, our approach allows a harmonization of delineations.

For cities, the comparative definitions and their associated implementing delineations address both conceptual and methodological questions $(1,2)$ that are applied differently in different parts of the world (3). We propose to summarize these issues in order to explain the choices and compromises contained in our own methodology used to define cities (4). These delineations are far from perfect and complete, but we hope that the open publication of the LUR COMPOSITIONS (Appendix 1) will generate reactions, complements and criticisms, leading to the improvement and updating of the delineations.

\section{The city as a social phenomenon}

The universality of cities continues to generate numerous controversies with a long history (1.1). Rather than participating in these controversies, we review the most contemporary prominent ones and suggest that there is not one unique "best" definition; each particular definition corresponds to a specific question (1.2). In fact, the urban/rural distinction or cities' delineation addresses different needs of policies for regulations (1.3). In a very pragmatic way, depending on our problematic issue, the scale of approaches and the level of policy actions that would be relevant (1.4), we propose a methodology to define cities all over the world.

\subsection{Controversies on city}


We assume that cities are "systems within systems of cities" (Berry, 1964) where socioeconomic interactions form the basic framework of each specific urban civilization. In fact, the word "City" comes from the Latin word "civitas", which is also the root of the words citizen and civilization. Thus, the concept integrates legal, institutional, social, and economic relations. It leads to an acceptation of the city as a specific dense place of social, institutional, economic, cultural and physical networks. It is however very fuzzy, as it depicts several organizational "realities" varying in time and space.

In studies of long periods, historians and archeologists identify the apparition of cities as spatial settlements consisting of sedentary households and characterized not only by a formalized internal organization but also by a developing regional surrounding organization (mostly for agriculture and commerce but also for political, religious and military power) (Bairoch, 1985; Chase-Dunn et al., 2005; Hanson, 2016). Concretely, in the identification of cities, historians and archeologists used the following set of indicators:

- An area with a higher density than the surrounding areas, as calculated both by the built-up archeological footprints and by the area's potential for the production of necessary food;

- The diversity of non-agricultural activities (that are assumed to be complementary and to generate local exchanges); and

- The identification of a central power.

Writing about the Roman Empire, Fustel de Coulange (1866) stated the distinction in the ancient societies between "city" and "villae"1. Accordingly, "the city was the political and religious association between families and tribes. The villae was the place of meeting, the settlement of this association (...). A villae was founded in one fell swoop, all in one day. But the city had to be constituted first, and it was the most difficult and usually the longest work. Once the families, "phratries" and tribes had agreed to unite and have the same cult, the city was immediately founded to be the sanctuary of this common cult. Therefore, the foundation of a city was always a religious act ..." ${ }^{2}$ (Fustel de Coulange, 1866: book 3). This is why, until now, the city represents both the social organization and the place where this organization meets, and these two meanings create some confusion in the definition, the approaches and the representations of cities.

Many debates occurred during recent years about the universality of cities' phenomena, and scholars were dominated by the "North" or "Western" conceptualization (see, in particular, the debates between Brenner \& Schmitt [2014] and Scott \& Storper [2015] and continued between Robinson \& Roy [2016], Storper \& Scott [2016] and recently Scott (2019)). Brenner and Schmitt (2014) criticize the use

\footnotetext{
${ }^{1}$ Even if Villae later became the common name for any property or group of properties in rural space, there remain two words in the French language: "cité" and "ville".

${ }^{2}$ Translated by the author.
} 
of the concept of the urban population threshold (UPT) to define cities, arguing that the concept makes no sense. One can acknowledge this criticism and, mainly depending on the context, can also reject UPT as a universal criterion. However, this must not prevent the consideration of cities as universal phenomena that can be conceptualized without any consideration of threshold of size. Following Storper and Scott (2016), we can consider that "cities are everywhere characterized by agglomeration involving the gravitational pull of people, economic activities and other relata into interlocking, high-density, nodal blocks of land use" (p.1116). Gravitational forces are created by a field of social energy rooted in numerous kinds of individual and collective interactions that create cities and reproduce their complex systems (Rozenblat \& Pumain, 2018).

The systemic multilevel approach leads to basically considering in a first stage that cities are "geographical entities that are produced through a common (universal) process of concentration of people and activities. Urban stakeholders not only cosettle and interact locally but also develop long distance exchanges, mostly aiming to maintain and expand the economic and social values of their urban assets" (Pumain, Rozenblat, 2018: xiii). At least at these two urban levels (local and regional/national/global), cities' systems have comparable processes of individual behaviors of mobility and bonding. This contributes to the building of local and global urban systems that may vary in their form depending on the time and space of structuring (Pumain, 2006; Besussy et al., 2010).

Moreover, following Henri Lefevre's (1970) argument that urbanization is generalized over the planet, Katsikis (2018) attempted to demonstrate the paradigm of "planetary urbanization" by defining concentrated urbanization areas or extended ones, including dense built-up areas for the former and human use spaces such as agricultural areas and woods for the latter. However, this demonstration is mostly based on land-use intensity and misses the other city dimensions and levels that characterize their complexity, i.e., the intertwined social and economic networks that intensify both locally and globally and transform spaces and resources. However, one can accept this approach as complementary to many others.

\subsection{Several partly overlapping cities' extensions}

Within the same urban context, several particular cities can be defined based on the research focus, such as a compact location for residences or for manufacturing (Built City), an area to which individuals commute for shopping (Commercial City), or an area to which individuals commute for employment (Employment city), as Parr (2007) theoretically proposed. More empirically, Mrad (2016) studied the coexisting and overlapping of accessible zones of cities (spatial potentials) with international 
functions, such as research and higher education, tourism, headquarters or airports, inside the extended urban areas of 125 European cities ${ }^{3}$ (Fig. 1).

Type 1: Six Major Metropolitan Areas
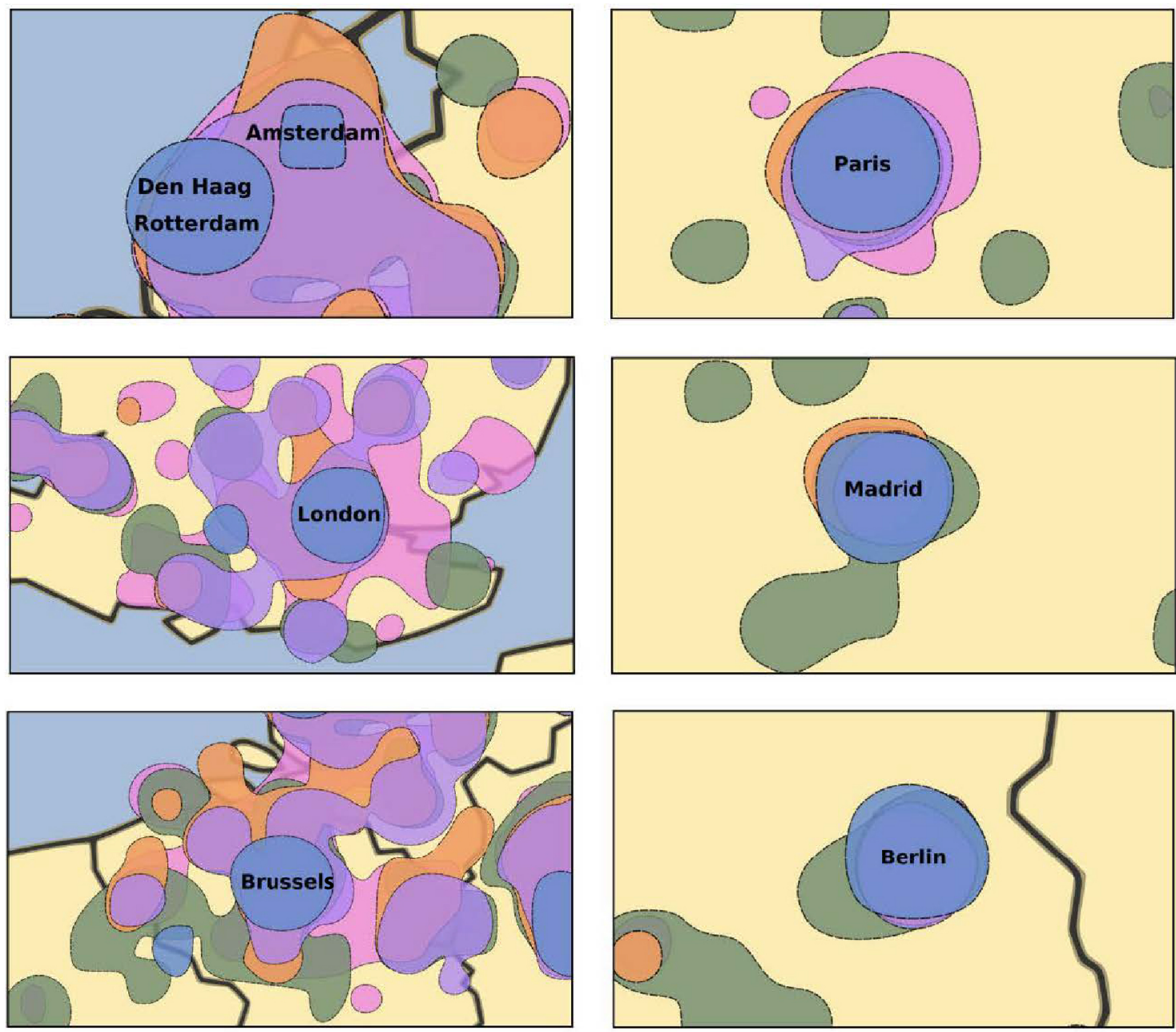

(c) M'Rad Mehdi, UNIL. 2015
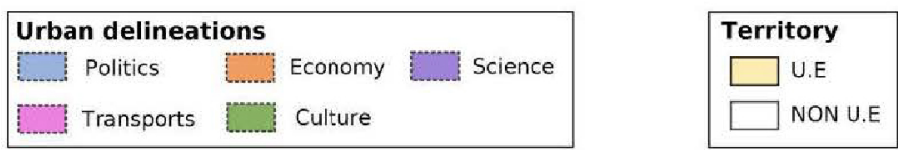

The different "types" seen are based to the "HAC" classification made on 10 indicators of overlapping (see Table 1 in appendix)

Figure 1: Spatial accessibility areas for five kinds of international functions in six major metropolitan areas in Europe (Mrad, 2016)

Mrad (2016) showed how much these international functions were centralized in the cities' cores and how far the influence areas of these international functions overlapped, especially the political institutions that are much more centralized than the other functions. Conversely, airports are located in suburbs, and cultural areas can be found in both central and fringe locations.

\footnotetext{
${ }^{3}$ This study was developed as a cooperation between the University of Lausanne and BBSR in Germany and was based on the data gathered by BBSR on European cities (BBSR, 2011).
} 
Of course, cities are much more than the coexistence of these partly overlapping functions or fragmented blocks. They are formed by the interlocking of all the occupations that strongly interact or that are sometimes practiced and developed by the same persons. In fact, urban processes, such as agglomeration economies, that are formed by direct or indirect networked exchanges leading to "sharing, matching and learning" (Duranton \& Puga, 2004) strongly necessitate variety and spatial proximity for formal or informal exchanges (Storper \& Venable, 2004). Firms need accessibility to various infrastructures and services; inhabitants, whatever their change of residence or change of job, also need many amenities based on indivisible economies.

However, proximity is a very relative concept (Torre \& Gallaud, 2020) and determines the propensity of people to move in the context of a certain place and of a certain period of history (Bretagnolle et al., 2000). Overall proximity varies according to the perception of the distance regarding the gain of this mobility, as the uneven distance decays of gravitational models depend on the purpose of mobility and routines (Grasland, 2010). For individuals, although the average travel time for commuters is found to have remained stable in history (Janelle, 1969; Bretagnolle, 2005), initially limited to one-hour daily travelling, some people can travel two hours or more to go to work if they have no other choice or if they can partly perform telework at home. When they want to access some valuable goods, cultural exhibitions or performances or when they need specific services, journeys can be planned, can be combined for several activities, and can take much more time than the simple journey to work that must be done every day. For firms, proximity is a longer-term matter, not one of daily convenience. Rather, proximity represents the insurance that the firms' employees can meet some subcontractor in the current week for a technical meeting or that the firm can have access to adequate workers, as well as diverse high-level services, institutions or infrastructures of transport and telecommunication.

Beyond the urban characteristic of these spaces, the issue here is the accessibility for most of the people, or for most of the firms, to what they need or they want and the ability of institutions to regulate in an equitable way this accessibility in the adequate perimeter. One can wonder if it is necessary to define a new institutional urban perimeter for every activity of people and firms in the city as Parr (2007) or Maisonobe et al. (2018) suggest. In a way, we could say yes, because as they assume that every kind of activity defines new mobilities and interaction behaviors. Despite this evidence, it seems difficult to define so many perimeters (with their respective institutions) for every theme and function that cities offer. In addition, the city is not formed by only one function but by the intertwining of them, and thus, the perimeter would correspond to a different degree of the combination or the overlap of different perimeters, corresponding to different institutional levels that are supposed to regulate them. 


\subsection{Issues of defining cities for policies of regulation}

The nature and intensity of urbanization implies policies for the adapted governance of territories for which the delineation of the phenomenon is necessary. In this respect, the "urban transition", meaning the shift from a worldwide society with a rural dominance to an urban dominance, has attracted much interest for more than fifty years (Davis, 1969, 1972; Champion \& Hugo, 2004; Rozenblat \& Pumain, 2018). Intending to alert civil societies and governments, many statistics were claimed. The statistic asserting that the urban population was $50 \%$ of the world's population in 2007 (UN, 2007) or the statistics in Koolhaas' Mutations (Rozenblat, 2000) were first published to engage the public in the awareness of the urban conditions becoming dominant in the world. These claims never pretended to be exact, as no statistic on population can ever be exact, but were always aimed at indicating tendencies and at supporting discourses and visions for planning the future of society. One must consider them as advertising, and all the essays and worldwide production of urban statistics deserve praise for their valuable trends' approximations that supported these visions.

The endless call for more rigorous measures (Satterthwaite, 2010; Brenner \& Schmitt, 2014) neither falls within the reality of the possible nor within the one of the desirable. The world urbanization "state-istics", as coined by Brenner \& Schmitt (2014), are not homogeneous by nature, because each country produces its own statistics, without any United Nations support (only recommendations), and each country uses these statistics for its own policies, which is the ultimate legitimate goal of producing statistics. Because urban policies are implemented inside each country (sometimes by two countries in case of border cities), it makes sense that according to its own history and context of territorial governance prerogatives, each country would define its own way to measure cities and its level of urbanization.

For concrete planning implementation, it is necessary that cities' definitions correspond to some administrative levels in each country. The administrative frameworks are necessary governance tools of control and regulation for national societies. However, on the other hand, many subsisting, very old administrative units no longer correspond to the "reality" of the urban expansion. To better correspond to common urban issues that they face, these administrative units would need to be incorporated or at least associated with larger governance territories. For US counties, this kind of association is claimed for a long time by Castells (1972). However, it is far from being achieved everywhere, and it remains an important revindication today for most urban places of the world (Phares, 2004; Sorensen \& Okata, 2010).

A larger perimeter for city governments was proposed in many countries, and most of the time, the process has been established by taking successive steps. For instance, in Great Britain, the first Local Government Act in 1894 defined urban and rural districts that have been regularly revised until now to constitute large metropolitan 
councils, such as the Greater London Council or the Greater Manchester Council, that regroup numerous suburban districts (Batty, 2018). Many countries followed this example and found that it was necessary in order to manage large metropolitan areas. In Germany, the cities of Berlin, Hamburg and Bremen have the benefit of a special status designation as city-states (Stadtstaaten). In China, cities are defined according to different administrative levels: towns (Zhen) comprise the lower level; then there are the district-level cities (Xianjishi), the prefecture-level cities (Dijishi), and the province-level cities (Zhijiashi) (Swerts, Liao, 2018). Inside the higher levels of cities, districts are classified according to whether they are centrally located $(\mathrm{Qu})$, located in the suburbs (also like district-level cities, called Xianjishi) or are located farther out in satellite areas (Xian). In Mexico, the Mexico City Metropolitan Area and the Metropolitan Area of the Valley of Mexico were defined in 2005 (Aguinaga et al., 2015). Since 2016, the power was reinforced in the Mexico-city center area, which is no longer called the Federal district but the Ciudad of Mexico, a new state entity in the federal constitution. In France, the communes' syndicates emerged in 1890, denoting areas where specific actions could be performed. This definition was broadened to include multiple tasks in 1959 through the emergence of intercommunal syndicates (Syndicats intercommunaux à vocation multiple-SIVOM). Urban associations were reinforced in 1992 with the creation of city communities (Communautés urbaines). In 2014, the power of these communities was redefined during a major territorial reform, while 14 of the largest French cities that were defined as a group of communes were designated by the state as metropoles, as they replaced some former local communities' governments, enlarging them spatially and in terms of their area of responsibility.

Many countries of the world engaged in such reforms to different degrees, which were often accompanied by decentralizations or the redistribution of power between the different regional interests, especially in terms of the collection of taxes and their redistribution (with movements of scaling up and scaling down: for China see Wu [2016]). The redistribution of local taxes between different local units belonging to the same urban system is a central issue because many inhabitants of peripheries use central services and transportation and thus may contribute to their cost of maintenance and development (Thiebout \& Houston, 1962; Castells, 1972; Lefebvre, 1970). The establishment of these urban governance parameters was partly defined according to the national institutes' statistical analyses that were adapted to the local historical and geographical contexts. According to the national and local kinds of democracy structures and functioning that have been widely discussed elsewhere (Bird \& Slack, 2007; Sorensen \& Okata, 2010; Faludi, 2015; Le Gales, 2016), the governance parameters were debated and decided by institutions.

Regardless of how they were established, these urban institutions regularly express the need to have insights on their own socioeconomic situation compared to that of other cities. In the way one approaches cities, it is thus necessary to not ignore this 
governance component, as the need to address it was established by the EU Urban Audits, the development of which faced numerous difficulties in different versions (Feldmann, 2008).

\section{Concepts to define harmonized cities and urban areas}

Thus, despite the universal phenomenon of urbanization, we cannot strictly have unique criteria of measurement at the world scale because of the unevenness of the densities, the culture and the histories of territorial appropriation and management. However, the impossibility of reaching a strict common definition does not mean that a harmonized definition is not possible. Pumain et al. (1992) suggested that "harmonization should be taken as meaning "meeting and having the same meaning as the clearly identified definition" without there necessarily being a perfect match with every criterion in the definition, but with criteria which, adapted to local realities, are capable of producing broadly comparable results" (p.7). In this approach of harmonization, different conceptual frameworks constitute guidelines for building comparative approaches. The conceptual consistency must lead to a harmonized comparison of cities or territorial levels and to an examination of different kinds of urban phenomena.

\subsection{Delineating cities by "urban fields"}

Above all, the delineation of cities addresses the identification of the neighboring urban spaces in the daily lives of individuals, groups or institutions, having numerous mutual common economic and social interests, interdependencies and sharing services, local urban and infrastructural planning or common economic or cultural strategic development. In the urban field approach, a fundamental assumption is that strong socioeconomic interactions link people in local spaces and that the local administration of territories is more advantageous for policy coordination than is separate administration. A large zone around each city benefits from spillover effects from the central core (or sometimes from several cores) where most of high-level services and functions are concentrated.

An "Urban field" (Pumain et al., 2006) develops around these cores "as a structured geographical area, generally according to a center-periphery model, by the inequalities of the urban land rent. The center-periphery gradient is a systematic variation in the intensity of land use and the price attached to locations, which decrease from the center to the periphery, exponentially as a function of the distance to the center (a gradient is a slope). This form is explained by the competition for the occupation of the central locations, which are the most accessible and the rarest, and also by the history of the cities, which is that of a spatial extension of the centrality, by 
diffusion of close by around an initial nucleus." 4 (Pumain et al., 2006). Depending on the history of the local urban spread development, regardless of whether urban development is centrifugal (Fig.2.A) or comprises the incorporation of neighbor settlements, a unique urban field can encompass several cities according to different situations (Fig.2.B) (Champion, 2001; Champion \& Hugo, 2004):

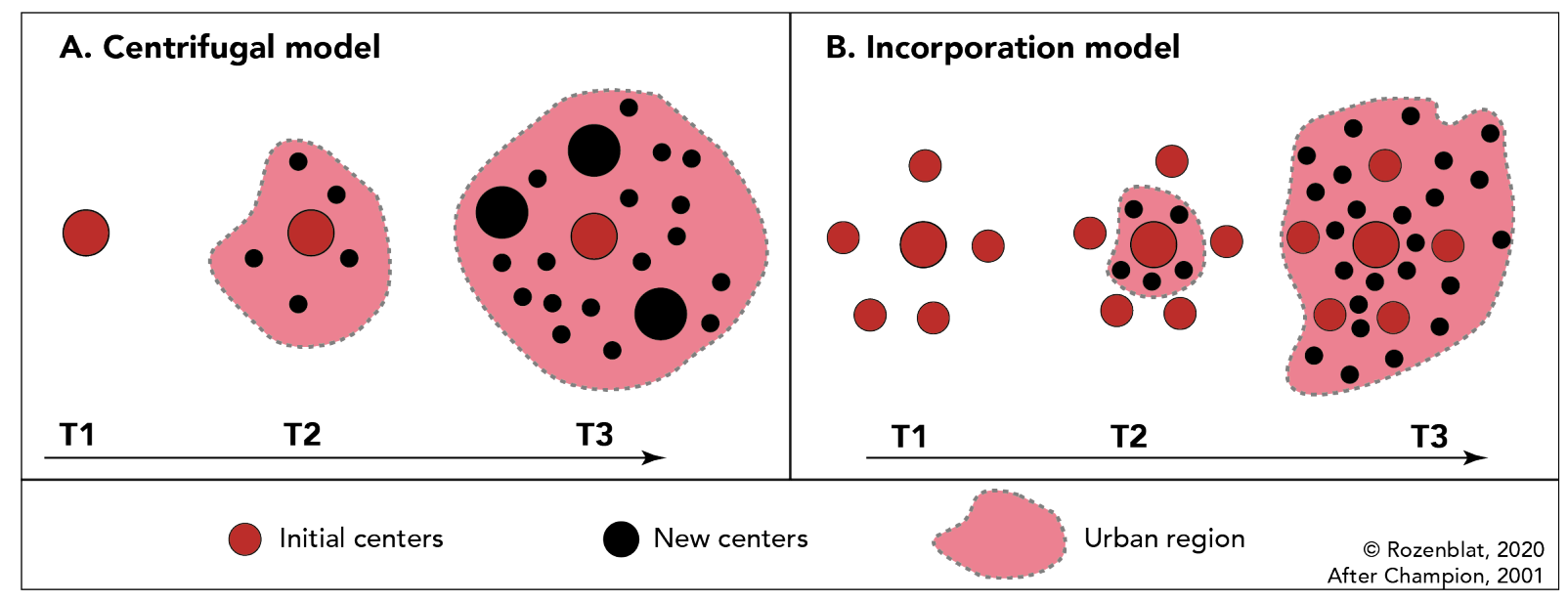

Figure 2: Two models of urban fields growth

A centrifugal pattern often emerges when there is a large city with historically strong regional power and in which most of the political, economic or religious functions are concentrated. The incorporated model appears in regions that are generally denser and where the power has been historically more fragmented (such as in Western Germany). Cities that are close to other cities have a higher and qualitatively different potential than isolated cities have, because potential is not additive but rather multiplicative, similar to network effects contributing to agglomeration economies (Rozenblat, 2010; Burger \& Meijers, 2016).

This potential, considered at different scales, is essential to define the cities' properties. Specifically, for integration into globalization, firms need access to a wide variety of high-level services and functions such as an international airport. However, overall, firms benefit from an urban field's social energy, basically framed in the multiple overlapping and intertwining socioeconomic local, regional and global interactions (Pflieger \& Rozenblat, 2010). This energy is the essence of the city and denotes the core of the difficulty in delineating cities. For example, in his early proposed description of the Northeastern American seaboard as a "Megalopolis", Jean Gottmann (1957) not only underlined the spread of dense urbanization in the polycentric system formed from New Hampshire to Northern Virginia but also insisted on the fact that "no other section has a comparable role within the nation or a comparable importance in the world. Here has been developed a kind of supremacy, in politics, in economy, and possibly even in cultural activities, seldom before attained by an area of this size" (Gottmann, 1961:3).

\footnotetext{
${ }^{4}$ Translated by the author.
} 
With the development of mobility and communication, these urban fields influence a further spread of settlements and in many cases lead to the organization of a large regional territory of mobility for services in a regional central place organization (Christaller, 1933). These urban fields also often integrate a regional division of labor for high-level skill industries (such as the Toulouse aeronautics industry, which integrates numerous subcontractors in satellite second tier cities, such as Montauban, Albi, Castres or Auch) (Markusen et al., 1999). In addition, all the urban and rural spaces in the urban field are under the influence of the cores, benefiting from the access to all their high-level services and infrastructures and impacted by the rent pressure and, to a more or less severe extent, other effects caused by the fields. Several medium-size cities often share many of these infrastructures, such as highspeed train stations or airports.

There is a temptation to approach urban field delineation by distinguishing inhabitants or enterprises. However, they are indivisible. Inhabitants move for reasons related to their job, shopping, leisure or services that necessitate having good physical access for daily mobility (Parr, 2007). Enterprises hire workers, conduct exchanges with other enterprises, use specialized services, have a specific central administration, utilize infrastructure facilities such as multimodal transportation platforms or airport and sell to markets in an area exceeding their local unit. Enterprises are attracted to locations with high quality workers, services and infrastructures. For example, following the spread of population, multinational firm locations in the Paris area are extensively dispersed in the Paris region (Ile-de-France) (Fig.3).

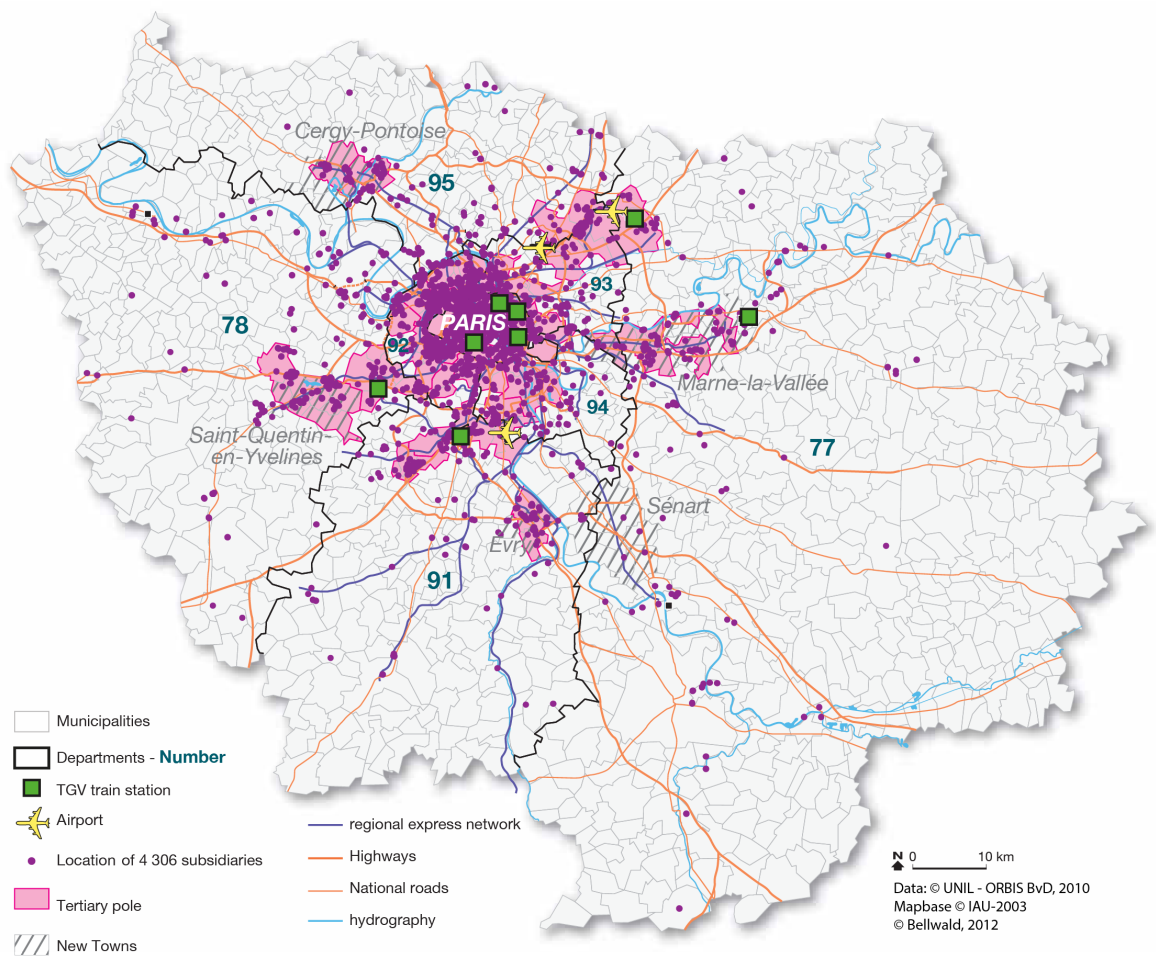

Figure 3: Location of multinational subsidiaries in the Paris region (lle-de-France) in 2010 (Rozenblat, Bellwald, 2013) 
Regarding the location of multinational firms in the Paris region (controlled from outside the region), a slight location effect was found in the new towns and a proximity effect was revealed for TGV stations and highways. However, the most important factors were the proximity to the Paris center and the accessibility to the three airports. In summary, all the firms located in the Paris region benefit directly or indirectly from the regional processes endowed by the dynamics of the Paris metropole.

Moreover, the fact that inhabitants, enterprises and institutions together form the city by their interactions explains why institutional aspects must not be neglected and why all their policies, actions and decisions affect indirectly the whole urban actors.

Many authors use the regional level to study cities, especially in Europe where NUTS2 and NUTS3 are informed by much more numerous statistics than those derived from the municipal level. If all the regions could be defined similarly to Paris, with a clear central city and a large region encompassing most of the urban field, it would not pose a serious problem. However, the lle-de-France region is a peculiar case: anticipating its growth and spread and thus making it very large, it was redefined in 1956 with some planning ambitions. Centered city-region (Fig.4-A) concerns most of the largest cities of the world. In many other cases of middle-size cities, either some regions encompass several cities (Fig.4-D), one city (and its field) is spread among several regions (Fig.4-C), or the city overpasses the limits of its region (Fig.4-B).

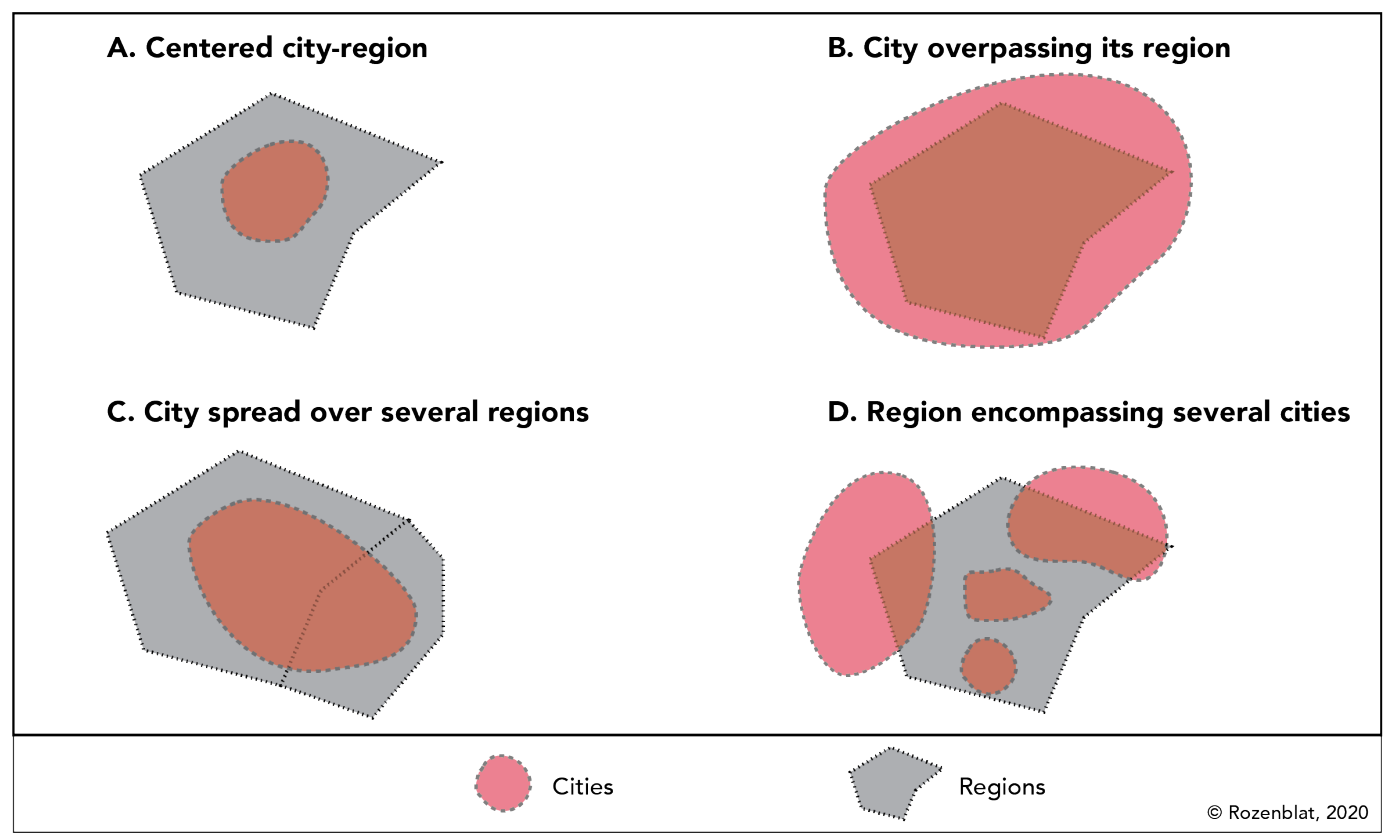

Figure 4: Limits of regions and cities' fields

Thus, in order to identify different kinds and levels of urban fields, a specific delineation based on the smallest units and a combination of different criteria is necessary. In addition, depending on the level of approach and the policy issues, different delineations and subdivisions are often useful. 


\subsection{Four concepts of cities for their delineations}

A wide set of sophisticated characteristics were proposed worldwide to define the urban nature and to delineate cities. However, they correspond to a limited number of families of conceptual approaches. Pumain et al. $(1992$, p.5) stressed a general classification of criteria of conceptualizing and statistically delineating cities according to different issues based on four main distinctive approaches:

- "Urban localities defined by the town's administrative boundaries or by its status in law;

- Urban agglomerations or urban units, which embrace continuously built urban centers forming either a part of one administrative unit or a group of several units;

- Urban regions comprising a nucleus town and its sphere of influence or employment catchment area, which are frequently defined in terms of commuting;

- Polynuclear urban regions, or conurbations, which when continuously built comprise a number of centers polarizing human dealings. They are frequently the product of a number of agglomerations or regions that, though initially separate, have become merged as a result of their geographical spread".

The issues and questions linked to these four approaches need to be further explained and discussed separately.

\section{2.a Urban localities}

Urban localities are very diverse in size and power from one country to another. However, they constitute the basic bricks (also called "blocks") of territorial planning management, and they must not be neglected. It is also at this administrative level that the statistics on sociodemographic and economic data are collected. Thus, it is in this framework that the most available updated socioeconomic data used to observe cities can be collected.

The criteria of population or employment numbers are often used in many countries to characterize these localities as "urban", with a threshold varying from 2,000 to 10,000 inhabitants. In fact, some countries give an urban status to all municipalities meeting only the minimal threshold of population and do not consider other indicators that could specify an urban character (this was the case for a long time in Italy and Spain). However, as discussed above, the relevance of such thresholds mostly depends on the urban localities' average size, which can vary greatly between countries or even inside the same country.

Additionally, by law with or without clear criteria, sometimes localities are designated at the national level as cities or urban localities. Governments give a legal status to capital cities or to other large cities, such as the district of Greater London, 
Copenhagen, Madrid or Barcelona. In other countries, such as Germany, Russia and ex-socialist countries, the urban status of all territories is generally defined by a legal status of "city" or of an "urban" administrative entity. Negotiations between the local and the central governments are key components of the urban status procurement process and involve a variety of personal and political elements (Rogov \& Rozenblat, 2020).

Another extended arbitrary delineation is the territory of local government encompassing several urban localities in metropoles. This delineation makes sense if this governments have real power, which is rarely the case. However, cities often spread outwards into peripheral areas of these administrative borders, and politics more often follow the urban spread with a large delay rather than, conversely, anticipating the spread. Thus, some statistical approaches are needed based on similar conceptual approaches to encompass all cities' extensions and dynamics.

\section{2.b Morphological Urban Areas}

Morphological urban areas (MUAs), also called urban agglomerations, refer to the continuity of the built-up area without being restricted to the administrative boundaries: they often go beyond the strict administrative unit of the city center, leading to the agglomeration of several contiguous units forming the whole urban agglomeration. Urban agglomerations are at the same time the oldest and the most used delineation in the world.

The urban agglomeration concept was first explicitly conceptualized in the European tradition of dense urban spaces aggregated to a central core (Meuriot, 1897; Geddes, 1915). It was much later implemented systematically by national institutes of statistics in the US in 1949, in Great Britain in 1951 (Parr, 2007) and in France in 1954 (INSEE, 2016). In total, in 1990, six of the twelve countries of the European community used the concept (Belgium, Denmark, France, Greece, Ireland, and Great Britain), in addition to Switzerland (Pumain et al., 1992). In 1978, the United Nations recommended that all countries of the world apply this delineation to cities.

In practice, until the end of the 1980s, the continuity of the built-up area was identified with areal pictures (taken by plane), and since the 1990s, it has been identified by remote sensing from satellite images. The compact zone covers all the construction not exceeding a certain distance from other construction. The chosen threshold distance can vary from 50 meters for Belgium or the United Kingdom to 200 meters for Denmark, France or Ireland (Pumain et al., 1992). In general, for an area to be considered an urban area, the continuity of the built-up areas is supposed to encompass all the urban functions, including parks and infrastructures. As pointed out by Parr (2007), "it may sometimes contain nonurban tracts. Physical impediments to urban growth, the existence of parks, nature reserves, areas devoted to sports, as well as the imposition (by planning authorities) of green wedges and other restrictions 
on land use, all account for such discontinuities in the urban surface" (Parr, 2007: 284). For example, the Netherlands was planned with a periphery of cities containing green spaces, which must be considered when one delineates cities (Cattan et al., 1999).

Remote sensing techniques and the diffusion of satellite images permitted the systematization of this approach in the 2000s. At the European scale, CORINE Landcover allowed the defining of a population density grid (Gallego, 2010) and Urban Morphological Zones (UMZ) (European Environment Agency - EEA, 2002; Milego, 2007). Bretagnolle et al. (2011a, 2011b, 2016) tested and compared the relevance of UMZ with that of other techniques, finding it provided very strong national specificities in terms of the densities of urban agglomerations. In addition, thanks to CORINE Landcover, Guerois \& Pumain (2008) showed that inside a sample of 40 European urban agglomerations, the densities decreased from the center; and another study (Guerois, 2003) observed a main discontinuity distinguishing the core gradient from the peripheral one, corresponding to the historic urban field and its more recent extension.

Among the many sophisticated methods used to delineate cities based on a built-up morphology (Gastler et al., 2001), the fractal approach considers more deeply the morphologic shape at a fine scale of the buildings' cadaster (Batty, 2004; Tannier et al., 2011). In addition, forming finger shapes along the roads, urban settlements usually concentrate along the roads permitting good access to the city centers. Thus, some additional conditions and rules are implemented to identify and isolate the extending agglomerations along these roads (Moriconi-Ebrard, 1994; Borruso, 2003; Salom \& Albertos, 2010).

Most of the time, whatever technique is used, the defined built-up areas are adapted ultimately to an aggregation of contiguous local administrative units in order to collect data on population and on economies. Some rules are usually followed to include or exclude each unit: an agglomeration-estimated population must exceed half of the total population of the unit, and a certain threshold is sometimes defined according to the country and may vary from 50 to 1,000 inhabitants. The minimal total population threshold of the defined urban agglomerations can vary from 2,000 to 10,000 .

All these urban agglomerations reveal the part of the urban compact environment where one supposes a maximum of interactions between inhabitants and economic activities occurs. In fact, it is assumed that people's movements and material and immaterial flows use common paths provided by local roads and public transportation, which appeared at the end of the $20^{\text {th }}$ century, shaping the cities' extensions. This compact built-up area comprised the area in which most of the activities of urban life occurred until the development of the individual vehicle. Because of this release of mobility caused by the use of the individual motor car, which first occurred in North America before the Second World War and occurred mostly after the war in European countries and other parts of the world, settlements 
spread around cities, forming an urban explosion that was no longer continuous with the city center. The influence of the city-systems' field was thus no longer well represented by urban agglomerations.

\section{2.c Functional urban areas}

Functional urban areas (FUAs) were introduced to address the issue of the noncompact form of urban sprawl, which appeared with the rapid development of the individual motor vehicle. Living far away from the city center where most of the jobs were still concentrated, many workers began to travel long distances every day to go to work. This form of cities represented a change in the spread of urban areas and exploded structures that were no longer determined by morphologic continuous shapes.

In the first half of the $20^{\text {th }}$ century, the US Bureau of Census addressed this issue by proposing for the 1950 census the use of the concept called the Standard Metropolitan Area (SMA), which was an area based on the flows of commuters traveling every day from residence to work. The center of an SMA is a county containing a nucleus town of more than 50,000 inhabitants, and the total group of counties forming the SMA must exceed 100,000 inhabitants. Multiple rules regarding absolute size, the kinds of residents' activities, daily commuters and phone calls, together define the counties that are regrouped to the nucleus center (Gottmann, 1957; Pumain et al., 1992). If two centers are less than 20 miles apart, they would be aggregated. The definition was simplified for the 1960 census, in which a new Standard Metropolitan Statistical Area (SMSA) was defined. However, considering these SMSAs too restrictive, Brian Berry strongly criticized this delineation in 1968, leading in 1973 to a revision of the definition by Berry and the Bureau of Economic Analysis; the revised definition was based on a national grid of "Daily Urban Systems" (DUS) and added other criteria, such as road networks, telephone traffic, newspaper readership or bank deposits. It resulted in numerous aggregations of adjacent SMSAs (Pumain et al., 1992). In total, the standards for delineating metropolitan areas were modified in 1958, 1971, 1975, 1980, 1990, 2000, and 2010. Since 2010, a metropolitan area has been defined as a Core Based Statistical Area (CBSA), which is "a statistical geographic entity consisting of the county or counties associated with at least one core (urbanized area or urban cluster) of at least 10,000 population, plus adjacent counties having a high degree of social and economic integration with the core as measured through commuting ties with the counties containing the core. Metropolitan and Micropolitan Statistical Areas are the two categories of Core Based Statistical Areas" (OMB, 2010).

In European countries, following this US pioneering work, the necessity to define functional urban areas appeared with a short delay (Pumain et al., 1992; Scott, 2019). The first scholars to propose functional urban regions applied it for use in the United 
Kingdom (Drewett, 1967; Hall et al., 1973). It was based on the definition of Metropolitan Economic Labor Areas (MELA) and Standard Metropolitan Labor Areas (SMLA). It was similarly implemented with some adaptations in Germany (Boustedt, 1975), in the Netherlands (Borchert, 1982) and in Ireland (Bannon, 1983). In France, this notion appeared in 1983, leading to the designation of "Employment zones" defined according to daily commuters (Mirabel database: Terrier, 1980), and in Italy, ISTAT built "labor markets" (Sforzi, 1989). In Spain, other criteria such as density and transportation replaced the commuters' statistics that did not exist (Ferrer Regales \& Precedo Ledo, 1982).

At the European scale, the seminal book of Dickinson (1947) introduced the cityregion concept and later, directly inspired by the US definition of SMA, Dickinson sought to apply it for Europe (Dickinson, 1964). Different initiatives followed, all of which were aimed at a harmonization of the delineation for European functional urban areas. However, all met the difficulty of the absence of statistics and the problem of adaptation to each country's specificity (Hall \& Hay, 1980; van den Berg et al., 1982; Cheshire et al., 1988). Bretagnolle et al. (2016) observed the existence of the urban regions' delineation in 14 European countries among the 30 countries of ESPON (European Spatial Planning Organization Network encompassing UE-28 and associated countries). Although the conceptual approach was similar for all countries and the approaches were all implemented based on commuters, the threshold for including a local unit in an urban region varied from $10 \%$ in Italy to $40 \%$ in France. Facing a large gap for many countries, Didier Peters of the Free University of Brussels applied some common criteria to delineate FUAs for all ESPON countries in 2012 (for an ESPON project and for the French Delegation of territorial Planning [DATAR]) and proposed a delineation containing a threshold of $10 \%$; i.e., an FUA would be delineated as an area in which $10 \%$ of its commuters travel to the center MUA (Halbert et al., 2012; Guérois et al., 2014). In comparison, the successive European Urban Audits $(2001 ; 2004 ; 2011 ; 2018)$ undertaken by Eurostat were underwhelming, mixing different delineations without justification or warning. EU publications on cities introduced more attention on delineation in their joint efforts with UN-Habitat and EU Join Research Center (JRC) ${ }^{5}$ (European Commission - UN Habitat, 2016).

\section{2.d Polynuclear urban regions, or conurbations}

The term "conurbation" appeared for the first time in Geddes (1915) in order to designate "coalescing clusters of overgrown British cities" after the early age of the Industrial Revolution (Batty, 2018). The polynuclear urban regions or conurbations concept is complementary to the functional urban areas' one, especially when several urban regions are close to each other, forming a continuous urbanization (Pumain et

\footnotetext{
${ }^{5}$ See below in Part 3 for more details about this collaboration
} 
al., 1992; Scott, 2019). Conducted simultaneously to Freeman (1958), describing in his "geography and planning" the continuous polynuclear urbanization, Gottmann $(1957,1961)$ illustrated in detail this form of urbanization in the northeastern part of the United States from Boston to Washington DC. In the USA, such polycentric regions were defined in 1990 as Consolidated Metropolitan Statistical Areas (CMSAs), which were formed by groups of contiguous Metropolitan Statistical Areas exchanging a significant proportion of workers. In 2000, the CMSA became the Combined Statistical Areas (CSA) under the following conditions: The Core Based Statistical Area (CBSA) of metropolitan and micropolitan areas exchanged at least $15 \%$ of their workers and that interdependence could be confirmed by an additional survey of local opinion or, without any survey, could be confirmed by $25 \%$ of their workers. The surveys were eliminated in 2010 and replaced by a unique criterion of $15 \%$. With the long history of change of delineation similar to CSA, the Office of Management and Budget (OMB) proposed recently a large historical reconstitution of data since 1950 until 2009, in the framework of the statistical area delineations for 2003.

Currently, numerous such conurbations can be identified all over the world: in Japan, from Tokyo to Osaka; in Europe, with the so called "Blue Banana" by Roger Brunet (1989); and in China, in the Pearl River Delta and around the two main capitals, Beijing and Shanghai. In Asia, the specific term of Desakota was introduced by McGee (1991) to characterize a specific form of dense urbanization and transport infrastructures mixed with a remaining dense agricultural land use. These Asian densities are not equivalent to those in Europe or in America. In the latter, by contrast, at the same time that McGee defined Dessakota in Asia, Garreau (1991) designated some large cities' satellites concentrating business and high-level activities as "edge cities". Very dependent on the automobile, these subcenters are part of a deconcentrated trend of the formation outside the traditional downtown area (or central business district), of city centers offering high accessibility and lower land rent, in order to attract large corporations (for example, proximity to the airports). At the end of the 1990s and in the beginning of the 2000s, often based on the existence of previous villages surrounding cities (Fig. 2.B), in a polycentrism perspective, the emergence of these satellites was supported by specific policies not only in the US but also in different European countries (Rozenblat, 2009).

For Europe, Hall \& Pain (2006) based the POLYNET project on the hypothesis of the forming of "Mega-city-regions" (MCRs) through the polycentrism development of numerous satellites cities in the surrounding regions of European global cities. Their delineation was not a premise of the project but rather an "overarching research question". Their collection of data and definition of the MCRs' boundaries were iterative; they defined initial areas that were based on commuters and that were rediscussed after deeper data analyses and key economic actors' interviews that better 
enlightened the regional functional relations. In this initial delineation, they first defined functional urban regions (FURs) as areas with the following:

- Cores as contiguous local units (NUTS5, today called LAU2) having a density of workers of at least 7 workers per $\mathrm{Ha}$ and a total minimum size of 20,000 workers;

- Rings that include all the local units sending more than $10 \%$ of their workers to the cores.

The delineation of MCRs was then based on an aggregation of contiguous FURs, and similar to the definition of CSAs in the USA, corresponded to the exchange of commuters between FURs. The output of their comparative study of eight European MCRs did not completely confirm their initial hypothesis of polycentrism: They observed a remaining concentration of major advanced services in the city cores and some strong national effects due to national policies. The peripheral satellites were rarely innovation poles, except for university centers such as Oxford and Cambridge around London or Louvain-la-Neuve in Belgium. The new satellites supported by states remained largely dependent on the core areas and offered activities that were much less diverse than the ones offered in the city centers. However, on the other hand, supporting the relevance of considering cities as large urban regions in an economic global perspective, they found strong economic linkages embedding the regional systems of MCRs.

\section{2.e Comparing Urban delineations}

The four previous kinds of delineations are applicable in the same cities. An example of different delineations applied on the bipolar urban region of Aix-en-Provence Marseilles reveals the issues and difficulties of any delineation (Fig. 5).
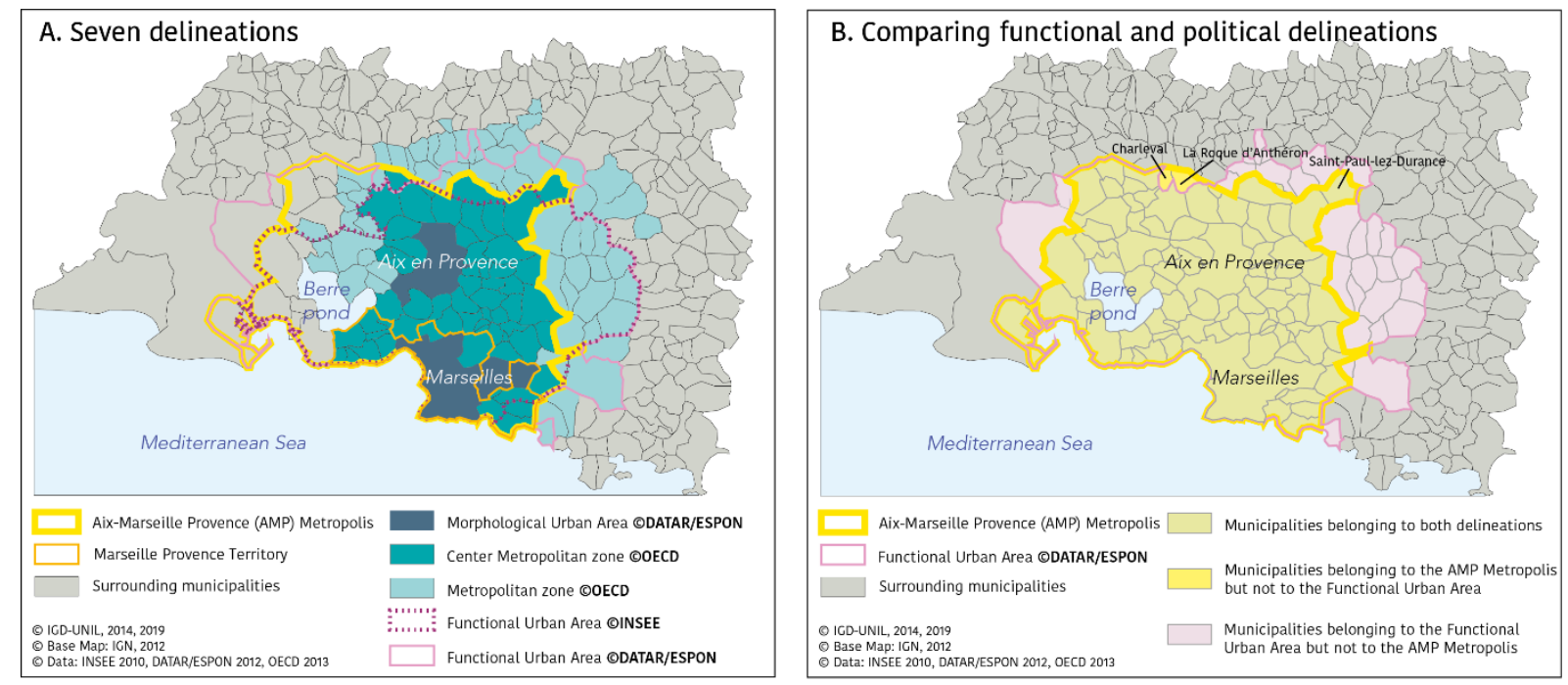

Figure 5: Compared delineations of Aix-en-Provence - Marseilles urban area

Seven delineations were compared during an applied project, which aimed at orienting the cohesive international strategy of the nascent Aix-Marseille Provence (AMP) political Metropolis (Rozenblat et al., 2015). The preliminary study attempted 
to evaluate the perimeter of the metropolis that originated from a pure political decision at the French National state level. The metropolis' perimeter encompasses 93 municipalities (yellow bold line on Figures 5.A and 5.B). The delineation is not very different from the functional urban area (FUA) defined by INSEE (Fig. 5.A) or by the FUAs of the DATAR project (2012) updated by the ESPON Database (2013) project (Fig. 5.B). These two previous delineations are both based on the commuters' statistics but do not exactly use the same method:

- INSEE measures the chains of commuters: after delineating the morphological urban areas (MUA) with more than 10,000 employments, the functional urban area (FUA) comprises all the municipalities sending more than $10 \%$ of their active population to the MUA or to municipalities already defined as attracted by the MUA;

- ESPON and DATAR projects defined the morphological urban area (MUA) and defined the FUA by adding all the contiguous municipalities sending more than $10 \%$ of their employees to this MUA.

One of the two municipalities that belong to the AMP perimeter but not to the functional urban area (in yellow in Figure 5.B) is La Roque d'Antheron, which has hosted a very famous international annual piano festival for 40 years. Representing an important urban event, it was strategically very relevant to include it in the political metropolis, even if it does not reach the threshold in terms of the commuters' dependence and employment density. As La Roque d'Antheron is integrated, as a spatial continuity issue, it was necessary to also incorporate it in the FUA of its neighbor municipality of Charleval.

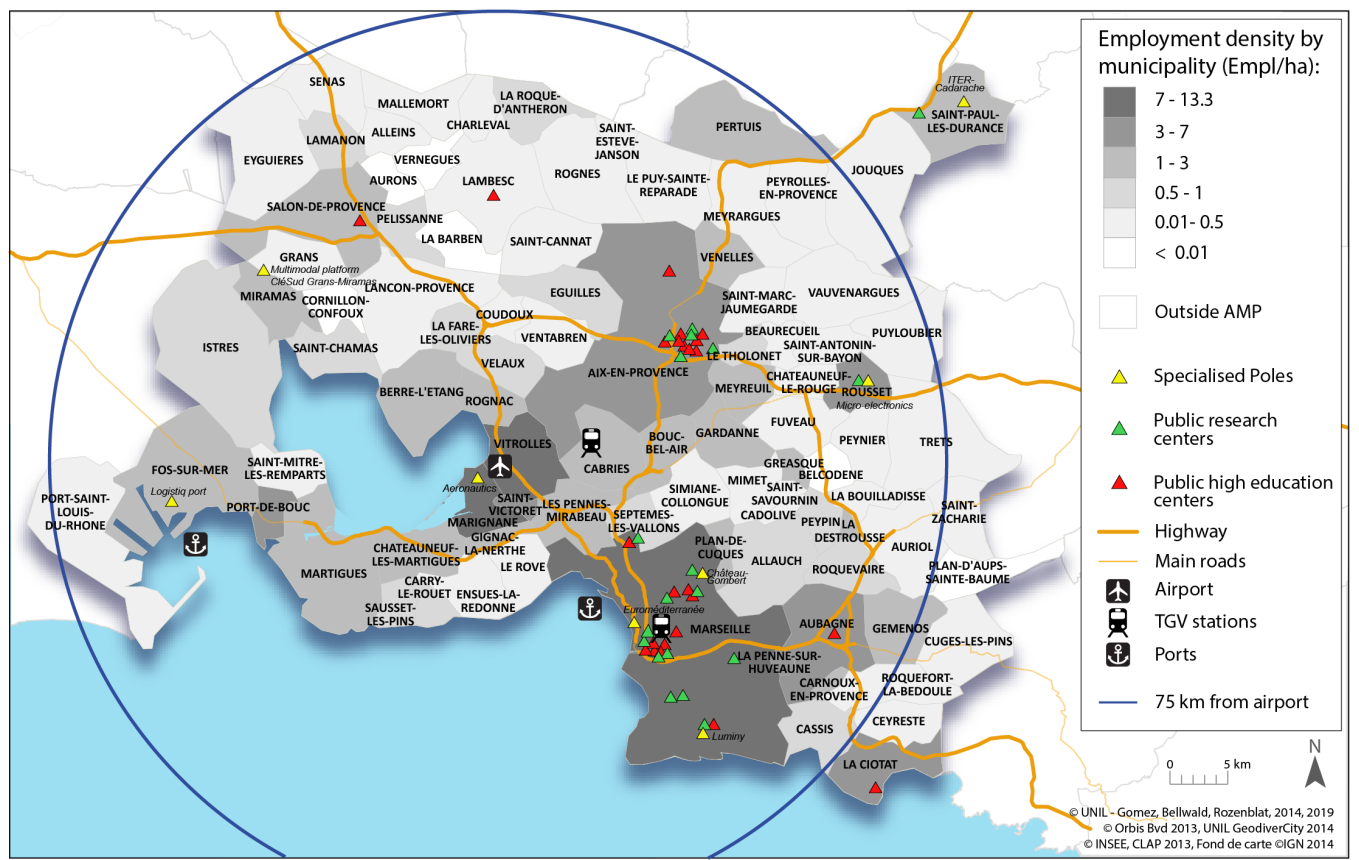

Figure 6: Densities and main infrastructures inside the Aix-Marseilles - Provence metropolis Another critical point located in a very strategic peripheral area of the AMP metropolis but included in both delineations is the municipality of Saint-Paul-lez- 
Durance (located North-East of the metropolis in Figure 5 and Figure 6). Saint-Paullez-Durance hosts the large ITER project at the Cadarache research center: built together by China, the EU, India, Japan, Korea, Russia, and the USA and associated more recently with Canada, Australia, Kazakhstan and Thailand, ITER is destined to become the largest International center of research on nuclear fusion of the world. The project has been on-going since 2006 and is planned to be operationalized in 2022. Despite its long physical distance to the metropolis center (represented here as the airport), Saint-Paul-lez-Durance should be integrated in the whole strategy of the metropole. This explains the north-eastern extension of the metropolis' perimeter.

In general, if one seeks to define the local system of a city by all its dependent/attractive areas forming the urban field, then using just the density of employment or the percentage of commuters is not sufficient and must often be complemented by the location of different strategic functions, such as specialized poles, research centers and higher education centers, as proposed in Figure 6. Again, the choice of functions to consider depends on the focused goals and on each city context.

According to the lessons learned from these past experiences, the main four concepts of the cities' definitions address different issues that have evolved in time with the cities' development. This has resulted today in a large choice of approaches that are able to answer simultaneously different urban questions. A worldwide approach of cities can rely on these conceptual approaches in order to reach a harmonized perspective.

\section{Worldwide initiatives on cities' delineations}

In the last 50 years, there have been numerous worldwide initiatives seeking to build harmonized data on contemporaneous cities. For 20 years, specifically regarding the impact of ecological issues on economic development, the key issue has been the warming climate. All these initiatives experienced the same dilemma of how to delineate cities in a comparative way. Following Bretagnolle et al. (2016) and Guerois et al. (2019a, 2019b), we propose to characterize these initiatives by their approaches, namely, either top-down methods or bottom-up ones. The top-down methods implement a unique method for all cities, while seeking to select the delineations based on similar concepts, the bottom-up ones use the existing national or regional delineations ${ }^{6}$.

\footnotetext{
${ }^{6}$ Note that these terms are employed here with a different meaning than that used in Davoudi (2009), which qualified "top-down, bottom-up" as the way with which the choice of the set of cities are done, or in the JRC/Eurostat top-down and bottom-up grid to disaggregate the LAU2 population (Dijkstra \& Poelman, 2014).
} 


\subsection{Harmonization with bottom-up methods}

The first attempt at developing a cities' description covering the whole world is usually attributed to Kingsley Davies $(1969,1972)$. However, Davies and his team at Berkeley used very blurred conceptual guidelines in collecting data on urban units with more than 100,000 inhabitants. Thus, the comparability was far from being achieved and the description has been largely criticized.

In contrast, always warning about the comparative issues, the United Nations started collecting urban population data by country in 1948 (Statistical Office of the United Nations \& Department of Social Affairs, 1949):

"One of the most difficult problems in presenting internationally comparable demographic data is that involved in obtaining urban and rural classifications of the population. The designation of areas as urban or rural is so closely bound up with historical, political, cultural and administrative considerations that the process of developing uniform definitions and procedures moves very slowly. In the tables of this volume dealing with urban and rural population and with the population by size of locality or agglomeration, the figures are presented as transmitted by the governments without any attempt to achieve greater comparability than already exists. In spite of the limitations to comparability, these data will be useful for many purposes. There are types of analysis and comparison that can be made without requiring complete uniformity with respect to the basis of classification. The limitations of the figures, however, should be kept in mind" (p.18).

Thus, the urban population tables always specify for each country the considered definition of "urban". In 1952, the UN published the first list of cities and the proportion of the population concentrated in different sized cities, especially highlighting cities with more than 100,000 inhabitants (Statistical Office of the United Nations \& Department of Economic Affairs, 1952). They then explained again that the difficulty in making comparisons is rooted in three kinds of problems: the uneven administrative local-governments, the existence or not of a national "agglomeration approach"7, and the unevenness of thresholds. They specify that there are "differences between countries in the way in which cities of 100,000 or more are delimited. Wherever possible, the urban agglomeration that includes the city was used for these computations, but in a number of cases, such figures were not obtainable and it was necessary to use instead the population of the "city proper",

\footnotetext{
${ }^{7}$ Here, "Agglomeration" refers to the Morphological Urban Area
} 
i.e., the administrative unit that bears the name of the city and often excludes suburban fringes, some of which are no doubt of considerable magnitude" (Statistical Office of the United Nations \& Department of Economic Affairs, 1952: 10). In the table depicting the population of capitals and of cities of 100,000 or more inhabitants, they distinguished the population according to two delineations of cities: city proper, meaning the administrative central city; and urban agglomeration, which is the morphological urban area. They explain it as follows: "In order to minimize the limitations to comparability arising from this source, figures are given, not only for the city proper but also, wherever possible, for the "urban agglomeration", which includes the suburban fringe or the thickly settled territory lying outside of, but adjacent to, the official boundaries" (p.25).

Since 1955, the Department of Economic and Social Affairs (DESA) and the United Nations Statistics Division have been in charge of the publication of these statistical yearbooks. Since 1969, they also published specific studies on cities of the world and numerous reports on individual Mega-cities. Since 1988, together with the UN Population Division, they published the World Urbanization Prospects, which was last revised in 2018. The two more recent publications of the World Urbanization Prospects (2014 and 2018) include a specific methodological report (United Nations, Department of Economic and Social Affairs, Population Division, 2018) and a file for each city specifying the sources and the adopted delineation selected from among three categories:

- "City proper", delineated by administrative boundaries;

- "Urban agglomeration", delineated by the morphological urban area;

- "Metropolitan area", delineated by the functional urban area.

They always gave preference to the urban agglomeration concept when the delineation existed, which was the case in 2018 for 74 up to the 232 countries of the world; a total of 13 countries provided metropolitan area statistics, 91 were only able to provide city proper statistics, and 52 countries delineated differently their capitals and the other cities.

Thus, in this bottom-up approach, always accompanied by a classification of the kinds of adopted delineations (compatible to the ones that we proposed above) and justifying this choice out of respect for the countries' "historical, political, cultural and administrative considerations", the UN gathered national statistics. Regarding the use of these very rigorous methodological explanations for all these statistics since the beginning of their publication, the UN publications on cities represent a fair model of statistical publication and going as far as classifying the data in order to avoid any misunderstanding and wrong comparison, are very explicit about the limits and

\footnotetext{
${ }^{8}$ See the World Urbanization Prospect archives: https://population.un.org/wup/Archive/
} 
properties of the collected data. The UN's approach does not deserve, in our opinion, to be considered as an aberrant approach or to be criticized by Brenner and Schmid (2014), who finally criticized only its bottom-up approach.

Alternatively, numerous other bottom-up approaches visible on various websites (such as those for Wikipedia, the World Atlas, the World Council of City Data (WCCD), the Global Cities Institute in Toronto, Global Sherpa, the World Population Review, and The Global Power Cities Index produced by the Institute for Urban Strategies of the Mori Memorial Foundation) claim to offer statistics on cities but do not offer any precautionary explanation or provide a definition of cities' delineations when comparing them. Due to the lack of any information about harmonization, these statistics must be used with a high degree of caution.

In addition to these contemporaneous issues, attempts to reconstitute the cities' growth were started very early by historians. One of the first attempts was the Chandler \& Fox (1974) study, which was based on multiple sources and offered estimations of the largest cities of the world since 1350 BC until 1968. This work was regularly improved by numerous contributors, such as Bairoch (1985), Chase-Dunn et al. (2005) and Hanson (2016). Historians collected data identifying and comparing a large number of sources, continuing the debate about these evaluations. The collections became increasingly more relevant thanks to the combination of archeology, history, demography, environmental science and complex systems that enabled the estimation of each single city's (in general urban agglomeration) surface, population and even infrastructures and richness (Hanson et al., 2019). The very interesting contribution of these approaches relies as much on the questions and doubts they pose as it does on the answers that remain open.

\subsection{Harmonization with top-down methods}

An opposite way to build the cities' data is the top-down approach, which applies the same method for every country. It necessitates a strong method and involves long and tedious work. The first construction of a database seeking to evaluate all cities of the world, applying exactly the same method in a top-down perspective, is certainly the Geopolis project built by François Moriconi-Ebrard (1994). MoriconiEbrard aimed at identifying urban agglomerations by using the criteria of a maximum of 200 meters between the built-up areas, following the French definition. Studying areal pictures, local sources and statistics in a very systematic way (and sometimes making field trips to verify the continuity of the built-up area), he managed to gather the population from 1950 to 1990 for every city of the world with more than 10,000 inhabitants. Mostly seeking to evaluate the urbanization trends in the most dynamic parts of the world, such as Africa (Moriconi-Ebrard et al., 2016), this large work has been updated several times since the 1990s (Moriconi-Ebrard \& Chatel, 2017). The 
GeoDiverCity ERC project developed further the comparative modeling approach of urban systems, based on urban agglomeration, for the BRICS, Europe and the USA (Pumain et al., 2016).

Since the availability of satellite image technology, initiatives flourished to compare cities of the world with systematic computing methods. In chronological order, the Oak Ridge National Laboratory built the first version of the Land Scan High Resolution Global Population Dataset (in short Landscan project ${ }^{9}$ ) in 1998 (Dobson et al., 2000). Addressing the problem of the uneven average size of local administrative units, they extrapolated, for all the countries of the world, the population of local units (Global Administrative Unit Layers dataset [GAUL] produced by FAO) to a grid with a resolution of $1 \mathrm{~km}^{2}$. Adapting the extrapolation of the size and precision of these local units to the grid cells and aggregating contiguous high-density cells, they obtained population density by cells that can serve to identify the cities' morphological boundaries (equivalent to MUA). Until recently, their approach has been regularly updated.

More recently, the OECD (2012) proposed a new definition of cities for their member countries based on the functional urban area (FUA) concept. The core of FUAs are "urban high-density clusters" identified as continuous built-up areas (MUAs), and the hinterland is delineated according to commuters or equivalent indicators. To delineate the core, the OECD used the previous Landscan project method of calculating densities in a $1 \mathrm{~km}^{2}$ grid cells and applied the method for Europe by using CORINE Land cover in collaboration with the Joint Research Centre for the European Environmental Agency (EEA). They were obliged to adapt some thresholds: Highdensity cells are considered with a minimum of 1,500 inhabitants per $\mathrm{km}^{2}$ in Europe, Japan, Korea and Mexico, but the threshold is reduced to 1,000 inhabitants per $\mathrm{km}^{2}$ in Canada and the United States. In addition, the minimal threshold size of these core is 50,000 people in Europe, Canada and the United States and 100,000 people in Japan, Korea and Mexico (OECD, 2012). To build measures other than population measures, they aggregated municipalities or equivalent administrative units (with more than $50 \%$ of their population belonging to the urban cluster) in order to constitute the urban cores. In a second step, they identified polycentric metropolitan areas if any urban core sends more than $15 \%$ of its workers to another noncontiguous core. Then, they delineated hinterlands as " "worker catchment areas" of the urban labor market, outside the densely inhabited core" (OECD, 2012: 28) and used the threshold of $15 \%$ of commuting workers. In this way, they identified 1,148 urban areas for the 28 OECD countries (comprising 649 metropolitan areas with more than 250,000 inhabitants). Since 2012, the delineations have been regularly completed and updated on their website ${ }^{10}$. They specify that for the harmonized approach, they "reduce to a minimum country specific adjustments in the methodology" and in case

\footnotetext{
${ }^{9}$ https://landscan.ornl.gov/publications

${ }^{10}$ http://www.oecd.org/cfe/regional-policy/functionalurbanareasbycountry.htm
} 
of non-access to relevant data such as commuting information, they use national experts. They publish the basic units' composition of each urban area, and a platform of interactive maps permits to explore the urban areas' properties, such as population, areas, GDP, income, labor markets or pollution ${ }^{11}$.

In parallel, the European Union Directorate General for Regional and Urban policy (DG Regio) launched a "harmonized definition of cities and rural areas" (Dijkstra \& Poelman, 2014). It consisted of a typology of Local Administrative Units (LAU2) based again on the population density in a grid of $1 \mathrm{~km}^{2}$ for all the EU territory and the European Free Trade Association (EFTA) countries (Iceland, Liechtenstein, Norway and Switzerland) and provided by the disaggregated population on CORINE land cover. The cells of the grid were first qualified by their population density. In a second stage, the contiguity of dense cells was identified, and in a third stage, their adjustment to LAU2s was determined: deepening the Landstat project and the OECD approaches, the results of these three stages enabled the identification of cities and three categories of LAU2 (Dijkstra \& Poelman, 2014):

1- "Densely populated areas" (cities) denoted by contiguous grid cells with more than 500 inhabitants per $\mathrm{km}^{2}$ and a minimum of population of 50,000 inhabitants, with at least $50 \%$ of their population living in the urban centers (or high-density clusters, i.e., contiguous grid cells with a density of at least 1,500 inhabitants per $\mathrm{km}^{2}$ );

2- "Intermediate density area" (towns and suburbs) with less than $50 \%$ of the population living in rural grid cells and less than $50 \%$ living in high-density clusters; and

3- "Thinly populated areas" (rural areas) outside the two first categories, including urban clusters composed of contiguous grid cells of $1 \mathrm{~km}^{2}$, with a density at least 300 inhabitants per $\mathrm{km}^{2}$ and a minimum of 5,000 inhabitants.

The adjustment from the grid to the LAU and the identification of cities were validated (and sometimes corrected) by the national institutes of statistics. This definition was developed in close cooperation with OECD and with the Joint Research Centre (JRC) of the European Commission's science and knowledge service (see below).

Now federated at the world scale, several of these initiatives are contained in the Global Human Settlement Layer (GHSL) initiative that was launched in 2010 by the JRC with the European Space Agency (ESA). The GHSL was linked in 2016 with other initiatives"1: "During the UN-Habitat III conference in October 2016, the European Union, the OECD and the World Bank launched a voluntary commitment to develop a global, people-based definition of cities and settlements. This commitment will support the implementation of the new urban agenda. It will also support the

\footnotetext{
${ }^{11} \mathrm{https}: / /$ measuringurban.oecd.org/\#

12 http://ghsl.jrc.ec.europa.eu/degurba
} 
monitoring and the comparison of the urban Sustainable Development Goal (SDG). Several of the indicators linked to this goal are highly sensitive to where the boundary is drawn around a city". The aim of this action was to present a top-down definition and methodology in 2019 to the UN Statistical Commission, which until now, as explained above, prioritized a bottom-up approach. The two linked definitions, namely, the degree of urbanization proposed by the UE DG-Regio and the EU-OECD functional urban area definition, are being tested.

Since 2016, the GHSL degree of urbanization has been available on the "Atlas of Human planet"13. This interactive platform combines a satellite approach based on a $1 \mathrm{~km}^{2}$ grid (Landscan project) and socioeconomic data to produce at the world scale the equivalent of the UE DG-Regio provided information on built-up areas and population for 1975, 1990, 2000 and 2015. The GHSL actions are extending to other rural aspects, as the Food and Agricultural Organization (FAO) joined the commitment in 2017 in order to improve its own statistics.

Thus, the Landsat, UE-OECD, UE DG-Regio and GHSL initiatives are developing in very close proximity and are coordinated in the GHSL, which is the place where all these projects meet and disseminate information to global institutions such as UNHabitat or the World Bank.

In addition to these related initiatives, the "Atlas of Urban expansion" ${ }^{14}$, a historical initiative launched by the New York University Urban Expansion Program in partnership with UN-Habitat and the Lincoln Institute of Land policy, has identified the extension of 200 cities in the world since 1990, including 30 cities since 1800 until 2000. They used historic maps for ancient periods and satellite images for the most recent one, thus coupling bottom-up and top-down approaches.

When defining cities, in all these top-down approaches, a problem appears similar to that in approaches using thresholds and absolute values. In fact, in a dense region, cities cannot be identified with the same density threshold as that used for a region of lower density. For example, in Asia, where cities' densities are higher, rural densities are higher as well. This is why the OECD initiative proposed to vary the thresholds. More generally, it is reasonable to maintain the proportionality between the thresholds and the densities, making thresholds relative rather than absolute. In this perspective, using Local Indicators of Spatial Association (LISA) in order to delineate "density nuclei" (Anselin, 1995), Maisonobe et al. (2018) proposed a delineation based on the decreasing slope of the population density from the core to its periphery. This sophisticated method permits a better consideration of the context of general densities and the avoidance of the strong bias of the basic administrative framework's variation size.

\footnotetext{
${ }^{13}$ https://ghsl.jrc.ec.europa.eu/visualisation.php\#

${ }^{14} \mathrm{http} / / / \mathrm{www}$.atlasofurbanexpansion.org/historical-data
} 
Currently, the top-down initiatives are very effective in reaching a harmonized delineation of cities and are supported by numerous worldwide initiatives. However, they still can be improved in better contextualizing their methods by considering local densities and national administrative organizations.

\section{Coupling Bottom-up/ Top-down methodology to delineate Large urban Regions}

Both bottom-up and top-down approaches have some advantages and disadvantages. There are absolute similar thresholds that facilitate comparisons when using top-down approaches. Despite the lack of harmonization of the thresholds in bottom-up approaches, the similarity of the conceptual approach helps to make the comparisons relevant. Therefore, a mixed approach is a good compromise between both.

The issue of producing a new delineation is twofold: first, it must follow a specific conceptual approach of the city corresponding to the goal of this delineation; second, it must use as much as possible the many existing works that we recalled earlier and that were undertaken by strong institutions with means and skilled people, both of which would be very difficult to match (and are not necessary to be reproduced).

\subsection{Concepts for delineating cities in a global perspective}

We aim at studying the dynamic of the cities' integration in global economic networks. As introduced in part 2.1, the firms' processes of networking and growing in cities rely on the whole urban field around each of them. This requires the adoption of a very wide conceptual approach to city delineation, i.e., one close to the polynuclear urban regions or conurbations we introduced in part 2.2.d. In fact, global cities are supported by larger surrounding polycentric regions, and it is important to capture all these dynamics when seeking to encompass the whole processes of globalization. The daily accessibility to global cities enables access to very diverse partners in face to face meetings (Storper \& Venable, 2004), to multiple intertwined networks bringing information (Pflieger \& Rozenblat, 2010), to public or private institutions, to skilled employees and to physical, transportation and financial infrastructures.

However, because the studies we develop must also fit with the "real" issues faced by territories and by their managers, they must be adapted to the framework of the governance at different levels of policies. In fact, we must also be able to address multiple delineations that usually comprise the administrative areas the policy-makers deal with. In addition, considering the systemic, multilevel approach of the urban systems, it is also important to be able to identify inside these large urban regions 
the different cores, their specializations and centralities. Because of this dilemma, we choose not to restrain our possibilities. This is why we have adopted a multilevel nested cities' delineation, which comprises four different conceptually harmonized levels.

\subsection{Delineation of cities in four nested levels}

Although the polycentric city-region is the main conceptual city delineation approach that is relevant to use for global networks studies, to address the economic integration at different scales, the inclusion of the subdivisions of each city-region is thus necessary. The four families of conceptual approaches for the cities' delineation presented above in part 2.2 constitute the main framework we have adopted in building our multilevel nested delineation:

- Urban localities that we called municipalities (MUNI). These areas represent the smaller territorial bricks one finds almost everywhere in the world, although they have very uneven power depending on the political national framework. They usually cover the whole national territory, except in the USA, where "Localities and towns" are very discontinuous in the counties' territories. However, in all cases, these localities represent the finest brick that can be entirely associated in higher scale cities' delineations.

- Morphological Urban Areas (MUA). In the denser parts of urban areas, we know that the concentration of all kinds of interactions is higher in these cores. These morphological urban zones are either capturable by the compact built-up areas, by the high density of the population, by employees or by firms. They encompass an entire number of all the contiguous MUNIs that are supposed to be part to the clustered compact zone.

- Functional Urban Areas (FUA). The functional zones according to the commuters' daily travels can be either measured by the commuters flows, or when this information is not available, they can be estimated by the density of roads or by public transportation permitting a one-hour accessibility to one or several cores. They usually surround one or several closed morphological zones, but in some very dense regions, a unique morphological urban area can encompass several preferential functional urban areas. Here, the settlement history and the geographic configurations intervene together to provide a deeper understand of the spatial interactions.

- Polynuclear urban regions that we called Large Urban Regions (LUR). The Large Urban Regions can have different configurations according to the presence of unique and quite isolated MUAs or FUAs or if there are several ones being close each other. Here, similar to what was done in the POLYNET project that concerned only eight European cities (Hall \& Pain, 2006), we had to make strong assumptions on local economic linkages between different MUAs or FUAs for the whole world. Similarly, we adopted an iterative approach, 
analyzing specifically the location of multinational firms of our database, their proximity to MUAs or FUAs, and their access to a main national or international airport, which was often situated in one MUA or FUA or between them. This last approach is quite new and original, but in the context of multinational firms needing rapid access to their subsidiaries, to markets and to high level services, the proximity to airports is crucial. Thus, it makes sense to consider airports as an important factor for the delineation of large urban fields that represent the polycentric regions supporting the integration of cities in globalization.

\subsection{Multiple iterative criteria for delineating cities}

According to these four levels of delineation, we developed a series of multiple criteria in order to define them in an iterative way. This approach was conducted in three main steps:

1- MUA, denoting the identification of the local units (municipalities) forming the urban cores and the extension of the built-up area in order to form morphological urban areas;

2- FUA, denoting the delineation of functional urban areas of these MUAs; and

3- LUR, denoting the delineation of large urban regions.

\subsubsection{Identification of MUAs}

The identification of the morphological urban areas (MUA) starts with the selection of cores that will constitute the centers. We do not use any threshold of population but rather identify the presence of multinational firms and of an airport, which often indicates an area with a higher density of population than that in the surrounding areas (Fig. 7.1). 


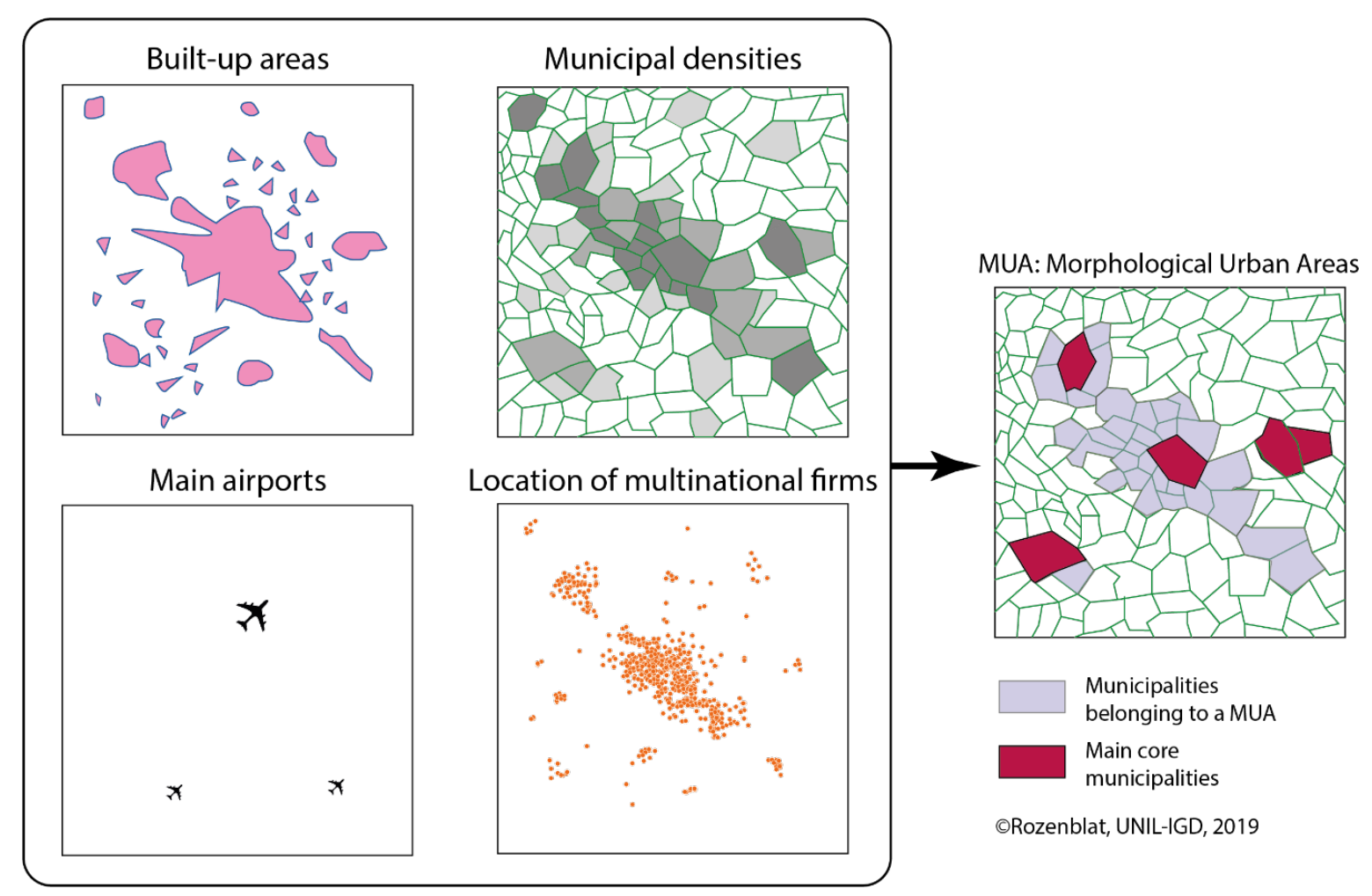

Figure 7.1: Step 1: Identification of cores and the delineation of MUAs

Following the concept of a morphological urban area (MUA), the surrounding builtup area is adapted to represent an aggregation of entire contiguous local units (municipalities) in which it is estimated that more than the half of their population comprises the built-up area. The name of the MUA is the historical core or is eventually denoted by several names associated with multiple cores.

\subsubsection{Delineation of FUAs}

The delineation of functional urban areas (FUAs) follows the usual concept of the dependent zones based on the workers' daily mobility (Fig. 7.2). 


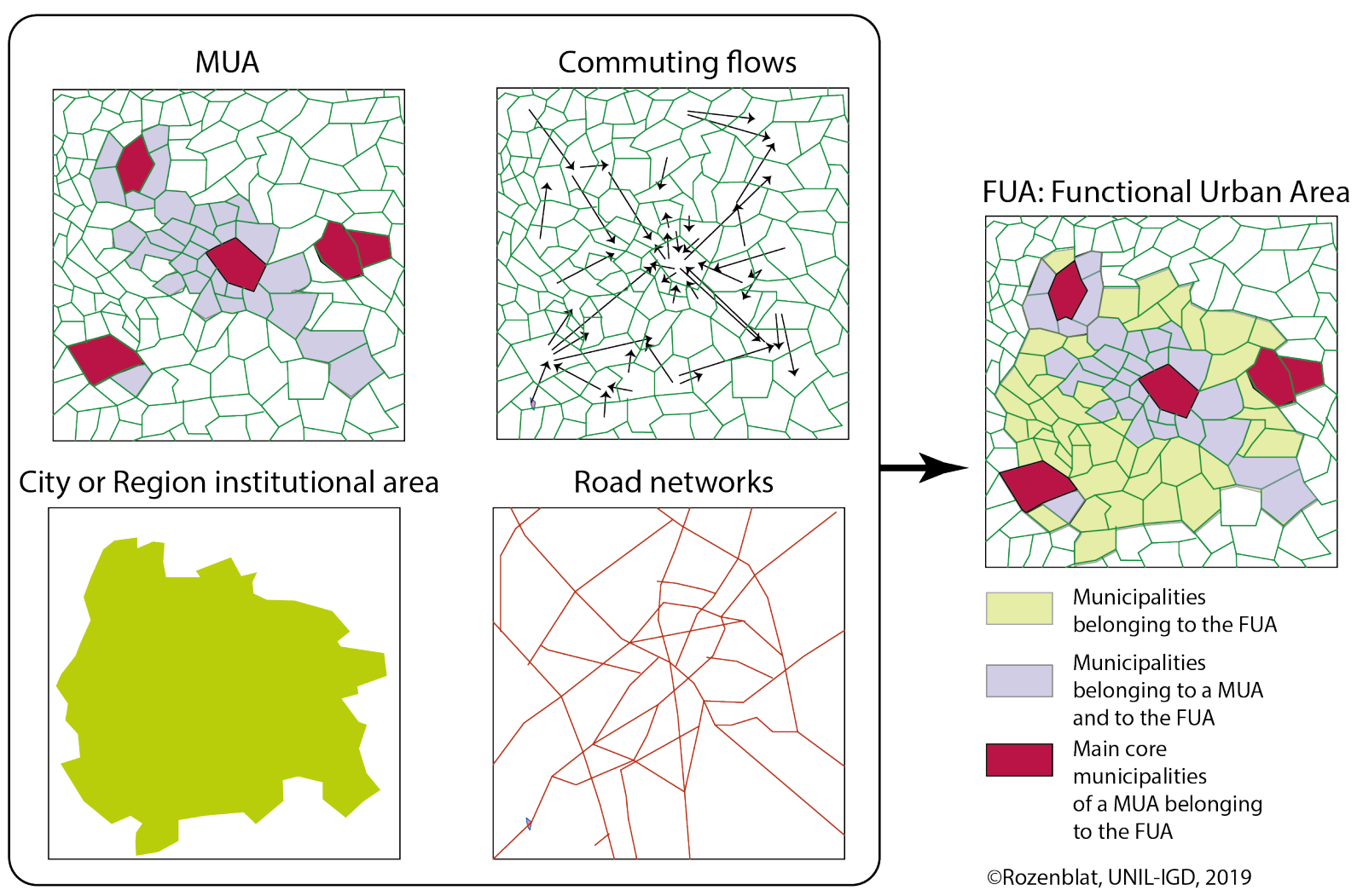

Figure 7.2: Step 2: Delineation of FUAs

The contiguous municipalities sending a relevant part of their workers to the MUAs are significantly dependent on the MUAs and are part of the Urban field forming the FUA. Simultaneously, the existence of an urban or regional institutional area with a strong governance structure reinforces this dependence. In the case of a lack of information regarding commuting flows, the road networks can identify the potential area of the FUA. Similar to the FUAs defined in the world (parts $2 \& 3$ above), the FUA can encompass a single center MUA or several MUAs if they are close and exchange a significant proportion of workers or are intertwined in a dense transportation network.

\subsubsection{Delineation of LURs}

Grouping entire regions connected to the world by the same airports, the delineation of large urban regions (LURs) is mostly based on the main airports' influence (Fig. 7.3). 

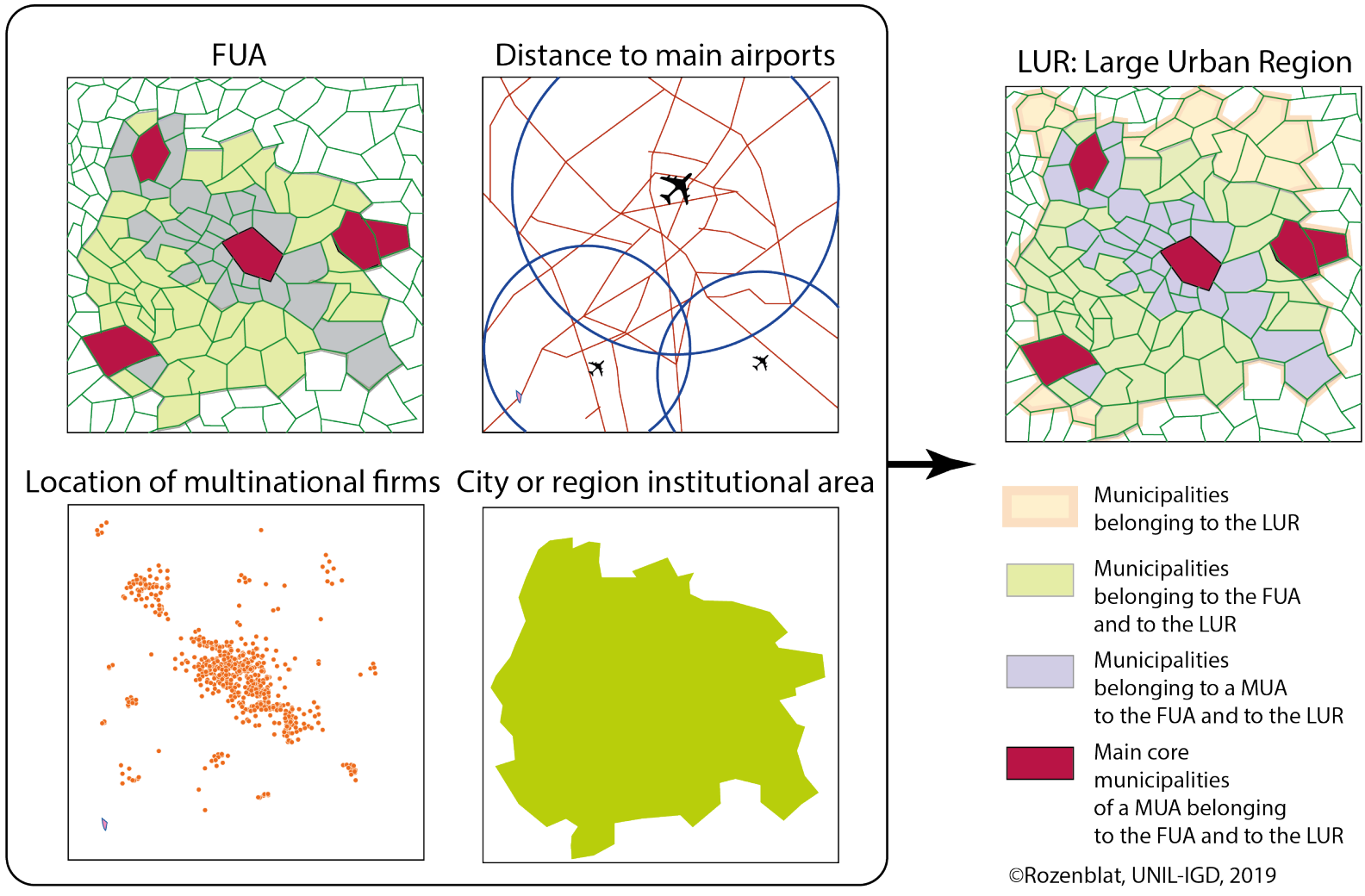

Municipalities

belonging to the LUR

Municipalities

belonging to the FUA and to the LUR

Municipalities

belonging to a MUA

to the FUA and to the LUR

Main core

municipalities

of a MUA belonging

to the FUA and to the LUR

Figure 7.3: Step 3: Delineation of LURs

ORozenblat, UNIL-IGD, 2019

The delineation extends to the encompassing of some single FUAs or can be defined by regrouping different FUAs and the zones separating them. For delineating LURs, discussing case by case whether or not to include some distant areas hosting some companies, specific attention was given to some isolated locations of multinational firms. This discussion considered the distance to the airport, the road networks, and the urban or regional institutional territory. Similar to the United States' combined metropolitan areas, the LURs include entire FUAs and the continuous spaces between them and, in the case of the inclusion of more distant areas, include the continuous intermediate space.

\subsection{Implementation of the delineation of cities}

In practice, we used as much as possible the existing delineations of MUAs and FUAs, which were either implemented by national institutes or by international initiatives as exposed in parts 2 and 3. Therefore, for the two first steps, we used a bottom-up approach, selecting the implementations corresponding to the concepts of MUA and FUA. The used sources for each country or group of countries are indicated in Table 1. 
Table 1: Sources for MUAs and FUAs to build the LURs

\begin{tabular}{|c|c|c|c|c|c|c|}
\hline $\begin{array}{l}\text { Countries or } \\
\text { groups of } \\
\text { countries }\end{array}$ & Basic Local Unit & MUA & Source for MUA & FUA & $\begin{array}{l}\text { Source for } \\
\text { FUA }\end{array}$ & Source LUR \\
\hline UE $28+$ EFTA & $\begin{array}{l}\text { Local Administrative } \\
\text { Units - LAU2 }\end{array}$ & $\begin{array}{l}\text { Morphological } \\
\text { urban areas }\end{array}$ & $\begin{array}{l}\text { ESPON / DATAR } \\
2012\end{array}$ & $\begin{array}{l}\text { Functional } \\
\text { Urban Areas }\end{array}$ & $\begin{array}{l}\text { ESPON / } \\
\text { DATAR } \\
2012\end{array}$ & \multirow{12}{*}{ 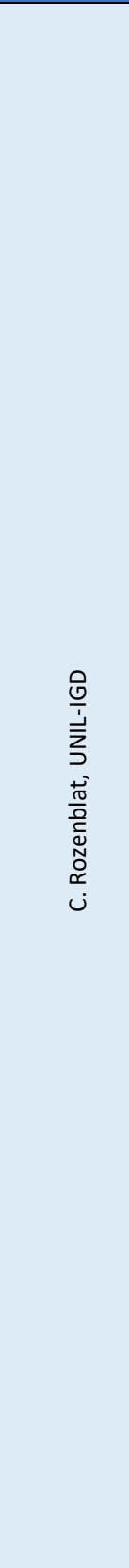 } \\
\hline USA & $\begin{array}{l}\text { Localities \& towns by } \\
\text { entire Counties }\end{array}$ & $\begin{array}{l}\text { Metropolitan and } \\
\text { micropolitan } \\
\text { statistical areas }\end{array}$ & $\begin{array}{l}\text { US CENSUS, } \\
2016\end{array}$ & $\begin{array}{l}\text { Combined } \\
\text { Metropolitan } \\
\text { Statistical } \\
\text { areas }\end{array}$ & $\begin{array}{l}\text { US } \\
\text { CENSUS, } \\
2016\end{array}$ & \\
\hline Canada & Counties & - & - & $\begin{array}{l}\text { Census } \\
\text { Metropolitan } \\
\text { Areas }\end{array}$ & $\begin{array}{l}\text { Census } \\
\text { Canada, } \\
2012\end{array}$ & \\
\hline Brazil & Municipios & Metropolitan Areas & $\begin{array}{l}\text { Instituto } \\
\text { Brasileiro de } \\
\text { Geografia e } \\
\text { Estatistica. }\end{array}$ & - & - & \\
\hline Russia & $\begin{array}{l}\text { Urban and rural } \\
\text { settlements by entire } \\
\text { Municipal district }\end{array}$ & - & - & $\begin{array}{l}\text { Municipal } \\
\text { districts }\end{array}$ & $\begin{array}{l}\text { Russian } \\
\text { LURs V1 - } \\
\text { Rogov, } \\
2020\end{array}$ & \\
\hline India & $\begin{array}{l}\text { Localities (towns \& } \\
\text { villages) }\end{array}$ & $\begin{array}{l}\text { Morphological } \\
\text { agglomerations }\end{array}$ & $\begin{array}{l}\text { INDIACITIES - } \\
\text { Swerts (2017) }\end{array}$ & Districts & $\begin{array}{l}\text { Indian } \\
\text { Statistical } \\
\text { Institute, } \\
2018\end{array}$ & \\
\hline China & $\begin{array}{l}\text { Qu/urban districts, } \\
\text { Xian/rural districts, } \\
\text { and Xianjishi/district- } \\
\text { level cities }\end{array}$ & $\begin{array}{l}\text { Morphological } \\
\text { agglomerations }\end{array}$ & $\begin{array}{l}\text { CHINACITIES - } \\
\text { Swerts (2017) }\end{array}$ & $\begin{array}{l}\text { Qu (Urban } \\
\text { district) } \\
\text { Shi (cities of } \\
\text { district level) }\end{array}$ & $\begin{array}{l}\text { National } \\
\text { Bureau of } \\
\text { Statistics of } \\
\text { China, } \\
2015\end{array}$ & \\
\hline Australia & $\begin{array}{l}\text { Cities, localities and } \\
\text { suburbs }\end{array}$ & $\begin{array}{l}\text { Morphological } \\
\text { agglomerations }\end{array}$ & OECD, 2019 & $\begin{array}{l}\text { Functional } \\
\text { Urban Areas }\end{array}$ & $\begin{array}{l}\text { OECD, } \\
2019\end{array}$ & \\
\hline Japan & $\begin{array}{l}\text { Municipalities (Cities, } \\
\text { Towns, villages) }\end{array}$ & $\begin{array}{l}\text { Morphological } \\
\text { agglomerations }\end{array}$ & OECD, 2019 & $\begin{array}{l}\text { Functional } \\
\text { Urban Areas }\end{array}$ & $\begin{array}{l}\text { OECD, } \\
2019\end{array}$ & \\
\hline Korea & Districts & $\begin{array}{l}\text { Morphological } \\
\text { agglomerations }\end{array}$ & OECD, 2019 & $\begin{array}{l}\text { Functional } \\
\text { Urban Areas }\end{array}$ & $\begin{array}{l}\text { OECD, } \\
2019\end{array}$ & \\
\hline Mexico & Municipios & $\begin{array}{l}\text { Morphological } \\
\text { agglomerations }\end{array}$ & OECD, 2019 & $\begin{array}{l}\text { Functional } \\
\text { Urban Areas }\end{array}$ & $\begin{array}{l}\text { OECD, } \\
2019\end{array}$ & \\
\hline $\begin{array}{l}\text { Argentina. } \\
\text { Bolivia, Chile, } \\
\text { Colombia, } \\
\text { Ecuador, Peru, } \\
\text { Paraguay, } \\
\text { Uruguay, } \\
\text { Venezuela }\end{array}$ & $\begin{array}{l}\text { Municipios, districts, } \\
\text { sectors, partidos }\end{array}$ & $\begin{array}{l}\text { Morphological } \\
\text { agglomerations }\end{array}$ & $\begin{array}{l}\text { CEPAL } \\
\text { (Comision } \\
\text { Economica para } \\
\text { America Latina y } \\
\text { el Caribe, 2009), } \\
\text { (Cuervo } \\
\text { Gonzalez, } \\
\text { Moura, 2018) }\end{array}$ & - & - & \\
\hline
\end{tabular}

For the delineation of LURs, we operated in a top-down approach, defining quite large urban zones in an iterative way through the location of multinational firms and airports and starting from the MUAs and the FUAs when their delineations existed. We made this a LUR-by-LUR operation, using assumptions on urban fields and studying in an iterative way the spread of multinational firms around each concentration of them. 
When we did not have access to existing delineations, we used principally the last stage to regroup close locations to unique LURs. This was primarily the case for firms located in Africa, as well as Middle East and South East Asia.

\subsection{Examples of delineations}

Some examples allow the review of different levels of choices during the implementation in three specific contexts: Switzerland, Russia and China.

\subsubsection{The Lemanic LUR}

For Geneva in Switzerland (Fig. 8.1), we used the ESPON delineation produced by Didier Peters in ULB for ESPON.

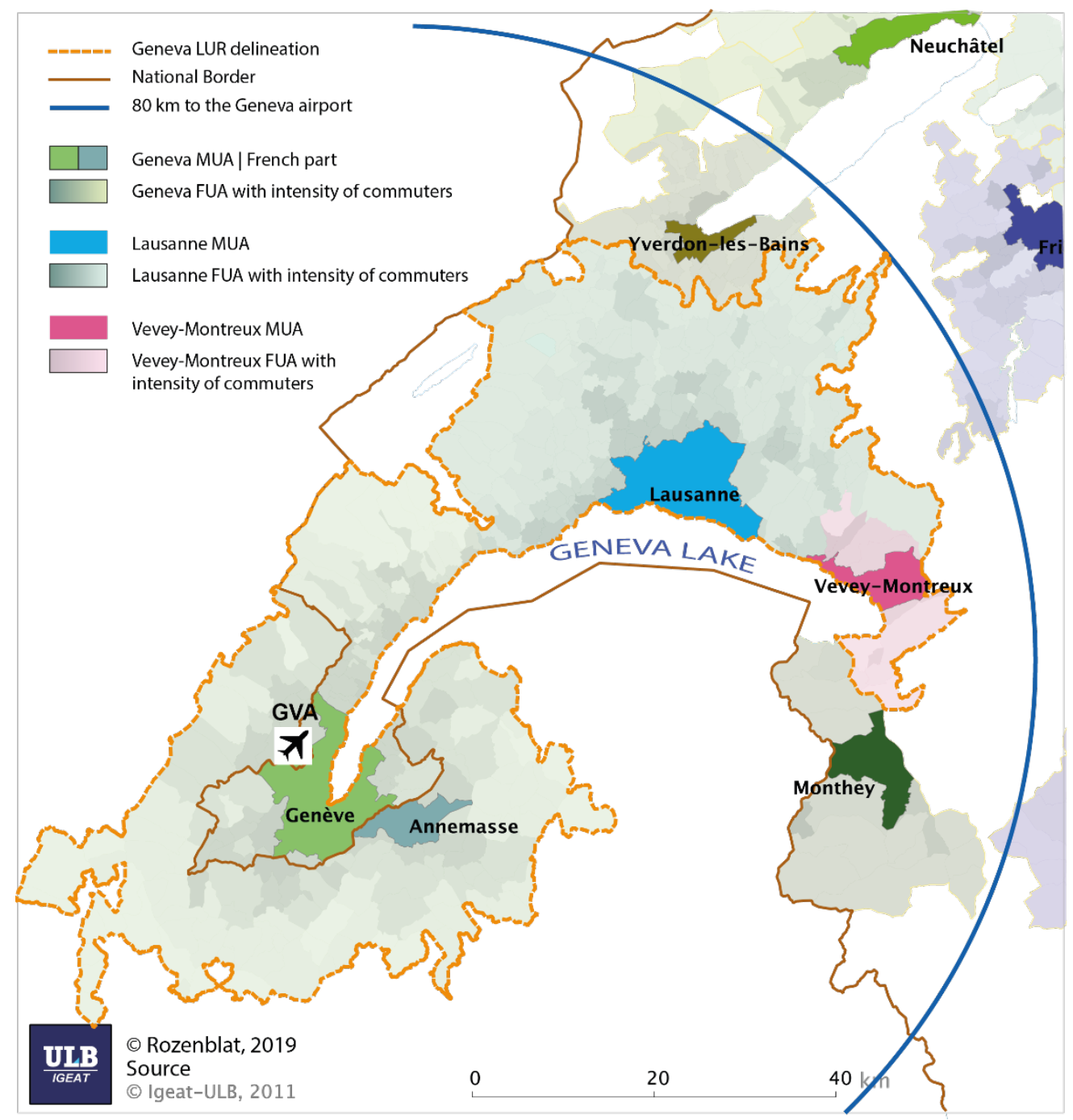

Figure 8.1: Delineation of the Geneva Large Urban Region (LUR)

Geneva is a border-city where $25 \%$ of the employees are trans-border workers (Canton de Genève, 2019). Along the frontier, French municipalities such as Annemasse are particularly dependent on Geneva. The GVA airport is on the border, 
and a part of the airport is a French property. On the other hand, the continuous urbanization along Geneva Lake toward the east is organized around the Lausanne and Vevey-Montreux MUAs.

These two cities of Lausanne and Vevey-Montreux maintain a certain economic independence and are in another county (Canton de Vaud). Lausanne hosts numerous headquarters, research facilities and universities but also hosts the Olympic committee, attracting numerous sport federations. Vevey is the worldwide headquarters of the Nestle Corporation, which in neighboring municipalities has distribution sub-headquarters and functions, such as a training facility (in La Tour de Peilz) and a research facility in Lausanne (Vers chez les Blancs). Moreover, thanks to frequent trains leading directly inside the airport, numerous commuters every day create intense commuter traffic between the three MUAs. The population and firms of the three MUAs use the GVA airport to travel. As proposed by Diener et al. (2013), we can identify a "Lemanic metropole" functioning along the lake. Four FUAs can thus be considered: Geneva, Lausanne, Vevey-Montreux and Monthey. The question is whether we incorporate Monthey in the southeastern part. As it is in a different administrative canton and is situated organizationally at a very strong political level in Switzerland, we decided to maintain it separately. Thus, the LUR regroups three different contiguous FUAs where we are fairly certain of their strong local interactions.

\subsubsection{The St. Petersburg LUR}

Another example concerns the Russian cities. In Russia, a city is principally defined based on status. The three main cities (Moscow, Saint-Petersburg and Sevastopol since 2014) are "subjects of federation" and at the same level of Oblast or Republic (Rogov \& Rozenblat, 2020). The other cities are recognized as specific municipalities that are considered urban neighborhoods. However, the influence of cities always exceeds their administrative borders. In the beginning of 2019, The Strategy of Spatial Development of Russia until 2025 delineated urban regions as a "set of compactly located settlements and inter-settlement territories, connected by the joint use of infrastructural facilities and united by intensive economic, labor, and social ties" (Rogov, Rozenblat, 2020). However, this delineation only concerns the 41 largest cities above 500,000 inhabitants (Zubarevich, 2019). Moreover, different authors had defined equivalents of urban regions since the 1970s (despite naming them "urban agglomerations") but did so without the use of commuter data that does not exist in Russia. In addition, few authors published the municipal composition of the built FUAs (Burian, 1973; Lappo, 1975; Polyan, 1980; Polyan \& Selivanova, 2007). The challenge thus does not entail using these works but building our own delineations (Rogov, Rozenblat, 2020). An example is given with the St. Petersburg LUR (Fig. 8.2): 


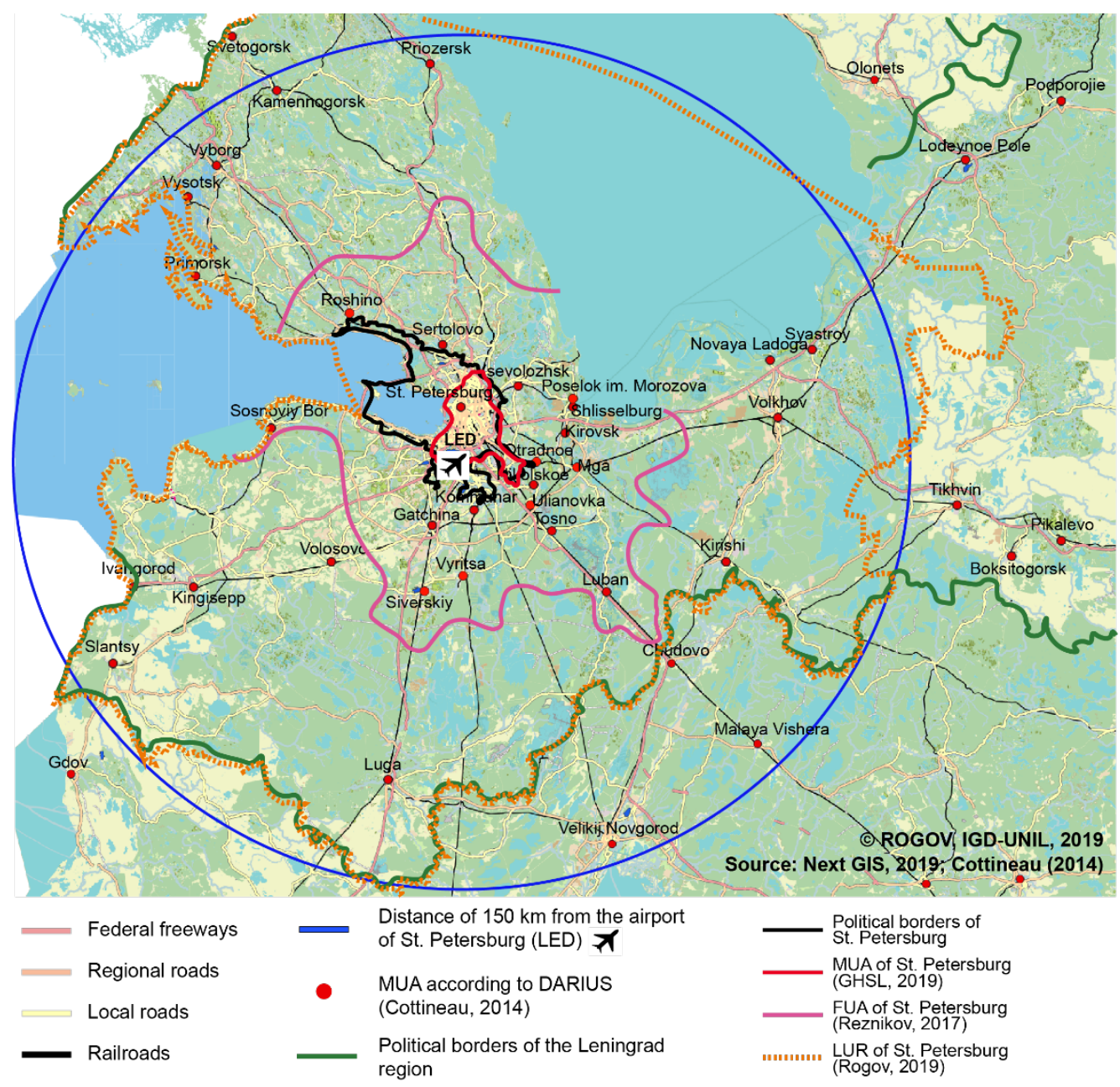

Figure 8.2: Delineation of the St. Petersburg Large Urban Region (LUR)

In St. Petersburg, the MUA defined by the GHSL (2019) (in red on the figure) is even less extended than the St. Petersburg administrative city itself (in bold black). Around the city, the Leningrad region encompasses many urban settlements identified by Cottineau (2014) as urban agglomerations (red dots). The functional urban region delineated by Reznikov (2017) integrates all the surrounding ones with a distance less than $50 \mathrm{~km}$, which seems very consistent with the FUA concept. For defining the LURs, Rogov \& Rozenblat (2020) had taken the whole Municipal rayons or urban neighborhoods with a distance less than $150 \mathrm{~km}$ to the LED airport and considering several other criteria: the road speed, the presence of multinational firms, and the inclusion of the area as part of the Leningrad region (strong political power is held at the regional level). The Municipal rayon level was preferred to the smaller municipal level, because it is the first level where statistics (other than population) are made available by Rosstat. We thus considered these areas as FUAs, listing their municipalities. Similar to this delineation of St. Petersburg, 113 LURs were defined in Russia.

\subsubsection{The Pearl River Delta LURs}


Given the political definition of cities with an addition of a very high density inside and between neighbor cities, China is even more complicated. The example of Guangzhou is given below (Fig. 8.3.A \& Fig. 8.3.B).

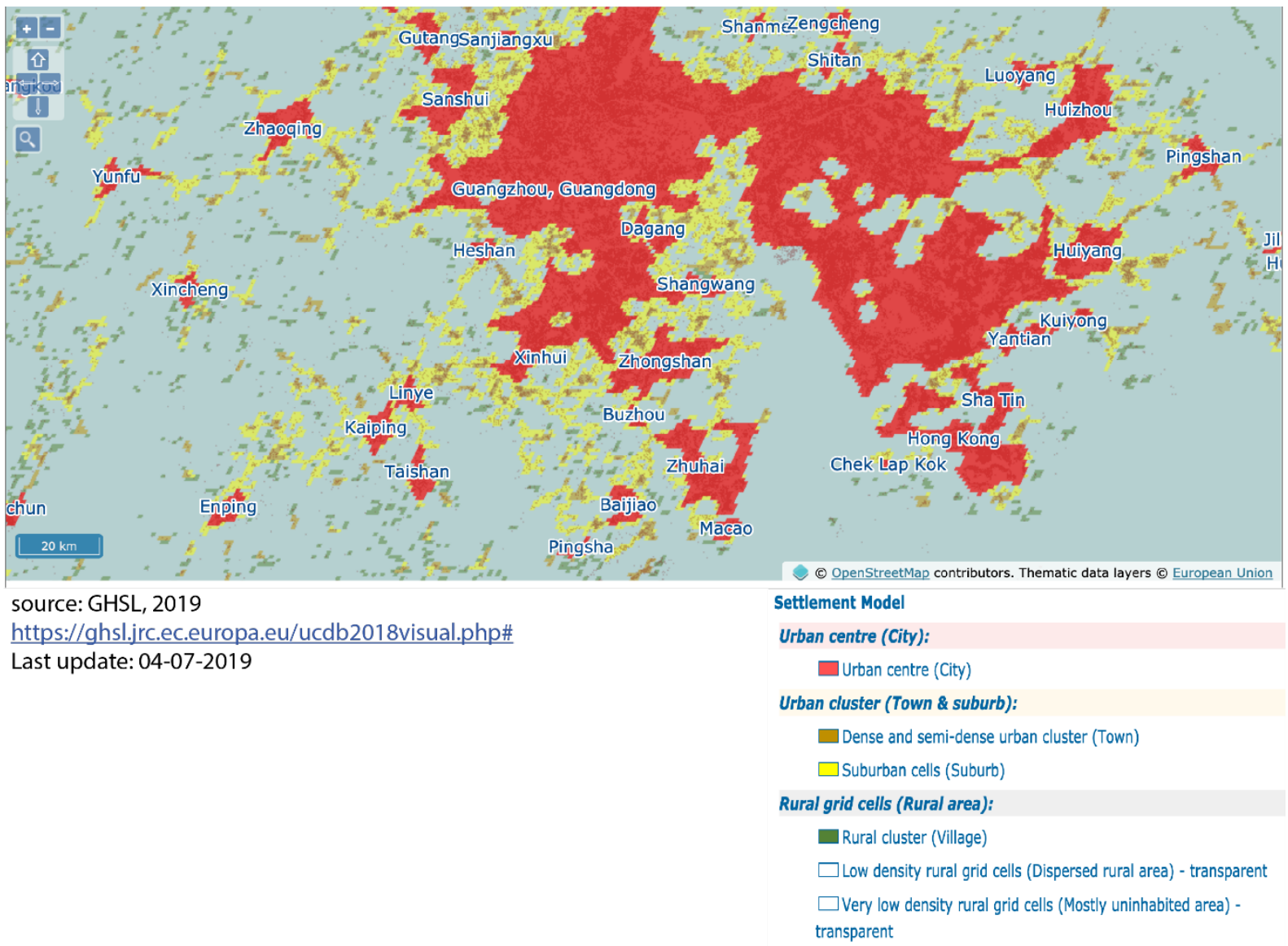

Figure 8.3.A: Delineation of the Guangzhou morphological urban agglomeration (source GHSL: 2019)

Delineating the Guangzhou urban agglomeration (Fig. 8.3.A), the GHSL initiative (2019) aggregated the entirety of the areas from Guangzhou to Zhuhai and Macao on one side of the Pearl River Delta and to Shenzhen and Hong-Kong on the other side of the delta. This results in the delineation of an urban area of 40.5 million people. The criteria, as presented in section 3.2, are the density of the resident population according to a grid of $1 \mathrm{~km}^{2}$ and the contiguity of the dense cells.

Using our multicriteria approach in a bottom-up and a top-down approach, we started from both the delineations of the morphological agglomerations (Swerts \& Liao, 2018) constituting the MUAs and the official prefectural cities' regions (generally encompassing one or several areas) that we consider FUAs. Note that some small MUAs do not have surrounding FUAs. Then, adding the intermediate rural areas in between these FUAS, Elfie Swerts regrouped the MUAs and FUAs according to the main national airports. In China, regrouping 657 FUAs, which represented a partial aggregation of 9,476 MUAs, Elfie Swerts defined 117 LURs (Fig. 8.3.B). 


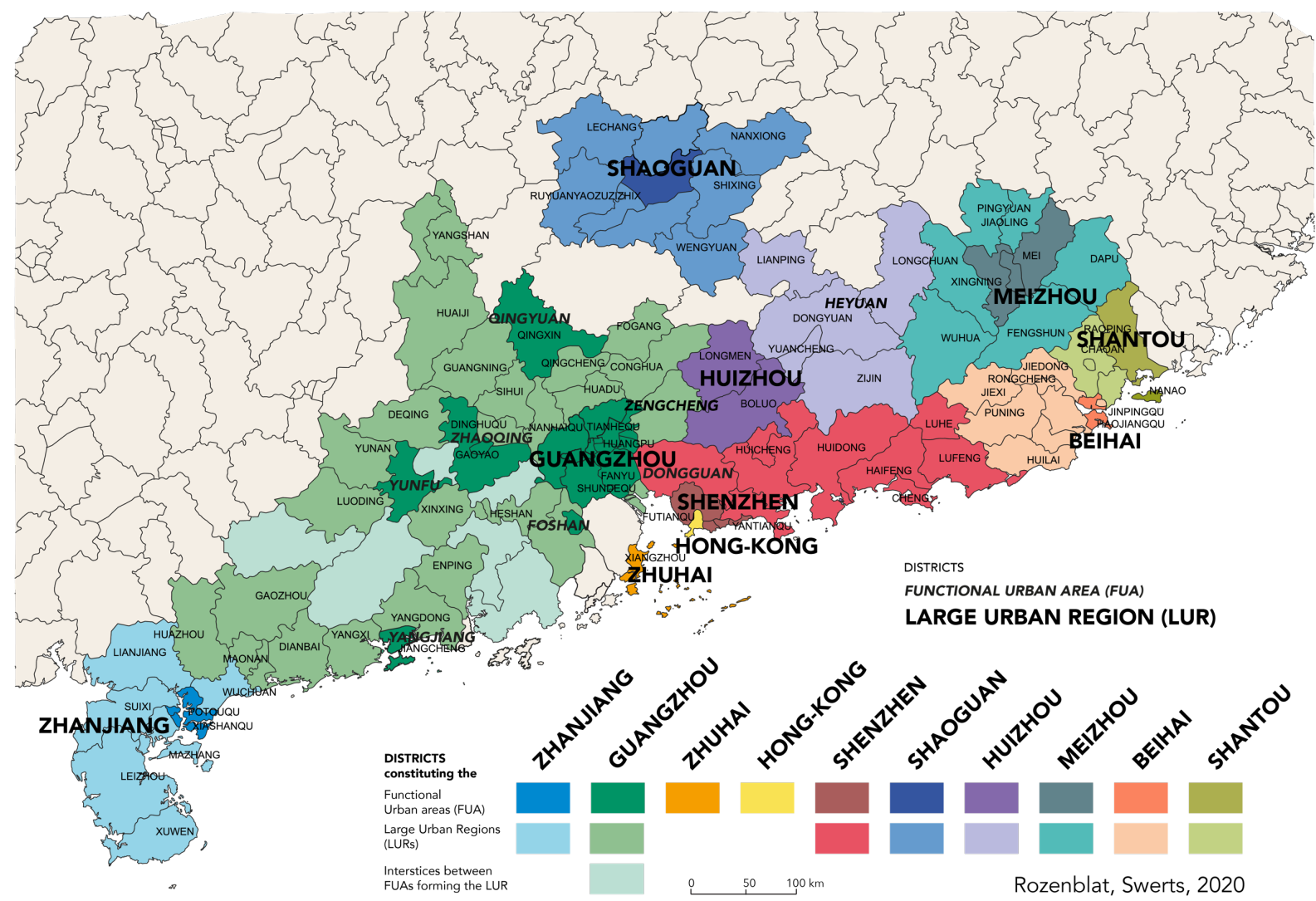

Fig. 8.3.B Large Urban Regions in the Pearl River Delta and Guangdong Province

In the case of Guangdong Province, the density is very high. Elfie Swerts (2017) identified the core-cities MUAs that represent subdivision of districts. Around each core, we defined FUAs according to the Chinese official delineation corresponding to district level (in Figure 8.3.B). Thus, we aggregated different FUAs in order to constitute consistent LURs according to a reasonable distance to main airports and to political considerations. Continuous areas between FUAs were also integrated in LURs. Thus, the Guangzhou LUR is quite extended but much less than the one defined by the GHSL (Fig.8.3.A). In fact, we maintained the distinction between Guangzhou, Shenzhen and Hong-Kong, considering that they constitute very distinctive urban regions constituting their own urban project for their economic development and their global issues, specifically for Hong-Kong which remains a particular political zone with a very specific role for multinational enterprises. Thus, the population of the region is distributed in the different LURs rather than being too much aggregated together (Tab. 2).

Table 2: FUAs and LURs population in the Guangdong province

\begin{tabular}{|c|c|c|c|c|c|}
\hline ID_FUA & FUA & Total Population 2016 & ID_LUR & LUR & Total Population 2016 \\
\hline CN4505 & BEIHAI & 1643700 & BHY & BEIHAI & 1643700 \\
\hline CN4401 & GUANGZHOU & 14043500 & \multirow{7}{*}{ CAN } & \multirow{7}{*}{ GUANGZHOU } & \multirow{7}{*}{37650500} \\
\hline CN4407 & JIANGMEN & 4544000 & & & \\
\hline CN4409 & MAOMING & 6123200 & & & \\
\hline CN4453 & YUNFU & 2480800 & & & \\
\hline CN4418 & QINGYUAN & 3846000 & & & \\
\hline CN4417 & YANGJIANG & 2528400 & & & \\
\hline CN4412 & ZHAOQING & 4084600 & & & \\
\hline
\end{tabular}




\begin{tabular}{|c|c|c|c|c|c|}
\hline CN4416 & HEYUAN & 3081000 & \multirow{2}{*}{ HUZ } & \multirow{2}{*}{ HUIZHOU } & \multirow{2}{*}{7856000} \\
\hline CN4413 & HUIZHOU & 4775000 & & & \\
\hline CN4414 & MEIZHOU & 4360800 & MXZ & MEIZHOU & 4360800 \\
\hline CN4452 & JIEYANG & 6094000 & \multirow{3}{*}{ SWA } & \multirow{3}{*}{ SHANTOU } & \multirow{3}{*}{14319200} \\
\hline CN4405 & SHANTOU & 5579200 & & & \\
\hline CN4451 & CHAOZHOU & 2646000 & & & \\
\hline CN4402 & SHAOGUAN & 2956100 & HSC & SHAOGUAN & 2956100 \\
\hline CN4415 & SHANWEI & 3036600 & \multirow{2}{*}{ SZX } & \multirow{2}{*}{ SHENZHEN } & \multirow{2}{*}{14945000} \\
\hline CN4403 & SHENZHEN & 11908400 & & & \\
\hline CN4408 & ZHANJIANG & 7273000 & ZHA & ZHANJIANG & 7273000 \\
\hline CN4404 & ZHUHAI & 1675300 & ZUH & ZHUHAI & 1675300 \\
\hline HKFOFUA & HONG KONG & 1675300 & HKG & HONG KONG & 7243500 \\
\hline
\end{tabular}

The region is dominated by Guangzhou with more than 37 million inhabitants, with two large urban regions reaching 14 million (Shenzhen and Shantou), three large urban regions with around 7 million inhabitants (Huizhou, Zhanjiang and Hong-Kong), and four other large urban regions between 1,6 and 4,3 million inhabitants. Of course, the contiguity between all these large urban regions results in a very dense urbanization, but interstices between them remain very rural, opposed to strong agglomeration effects in denser functional urban centers that are separated by several hundred kilometers. The example of this large urbanized zone is very representative of the homogeneous identification of the different conceptions of cities we introduced in this paper (MUA, FUA, LUR) that must be applied with similar rules considering the local context.

\subsection{The resulting set of LURs for the world}

In total, for the whole world, based on 128,642 local units, we defined 16,079 MUAs, 5,928 FUAs and 1,691 LURs (Appendix 1). The codes of local units, MUAs and FUAs are the ones used in the national censuses. For each LUR, we attributed the International Air Transport Association (IATA) 3 DIGIT letters of the main airport. Offering certain advantages, this code is very stable and universal; moreover, it is consistent with the criterion we applied regarding the proximity to a main airport. However, it must remain clear that the obtained geographic objects are large urban regions and not airports per se. For example, studying cities in the global air networks, we aggregate airports by LUR.

As a result of this multilevel delineation, based on its address, each firm location is now identified at the lowest level (MUNI) and can be aggregated the MUA, FUA or LUR levels. Providing a harmonized approach for delineating city-regions, this nested framework supports research studies regarding LURs at the world scale. In addition, often corresponding to some national policies, national studies can be developed in comparison to other studies conducted at FUA levels. Regarding local implications, MUAs composed by basic administrative units allow local governments to monitor their spatial planning of job distribution, residences and services, real 
estate and infrastructures. Despite the uneven power, size and properties of these basic bricks, their consideration is consistent with the need for some multilevel analyses focusing on each level in its specific context.

\title{
Conclusion
}

The world-scale approach of the delineation of cities is not prohibited by the diversity of urban phenomena. A deep review of the city concepts highlights that despite this diversity, some regular processes are revealed either through their performance at the administrative level (MUNI), in morphological urban agglomerations (MUAs), in functional urban areas (FUAs), or in large urban regions (LURs). These four concepts are complementary, and their relevance depends at the same time on the thematic of the research and on the scale of the study.

The proposed nested delineations of MUA-FUA-LUR use a coupled bottom-up and top-down approach, seeking to build these three levels according both to local specificities and to some conceptual guidelines making them comparable. It seems possible to address the issue of a multilevel approach of the insertion of cities into global trends.

The approach, which covers a large part of the world, can however still be improved, updated and made more complete. The project used specific projects on regions or countries to conduct a deeper examination into the state of the art and political organization of each national system. Publishing this database is the best way to open it to constructive criticism and to researchers, who are invited to provide their remarks and complements. We hope that a collective movement will follow this publication.

\section{Appendix 1: DATABASE OF THE LARGE URBAN REGIONS OF THE WORLD}

\begin{abstract}
This database provides construction of Large Urban Regions (LUR) in the world. A Large Urban Region (LUR) can be defined as an aggregation of continuous statistical units around a core that are economically dependent on this core and linked to it by economic and social strong interdependences. The main purpose of this delineation is to make cities comparable on the national and world scales and to make comparative social-economic urban studies. Aggregating different municipal districts around a core city, we construct a single large urban region, which allows to include all the area of economic influence of a core into one statistical unit (see Rozenblat, 2020 or Rogov \& Rozenblat, 2020 for Russia). In doing so we use four principal urban concepts (Pumain et al., 1992): local administrative units (Municipality or localities: MUNI), morphological urban area (MUA), functional urban area (FUA) and conurbation that we call Large Urban Region (LUR). The LURs are the spatial extensions of influence of one or several FUAs or MUAs. MUAs and FUAs are defined by various national or international sources. We implemented LURs using criteria such as the population distribution among one or several MUAs or FUAs, road networks, access to an airport, distance from a core, presence of multinational firms. FUAs and MUAs perimeters, if they form a part of a LUR, belong to a unique LUR. In this database we provide the composition of the LURs in terms of local administrative units (MUNI), Morphological Urban Area (MUA), Functional Urban Area (FUA).
\end{abstract}




\section{References:}

Aguinaga, E., Aranda, A., Ardis, L., Ferguson, G., \& Mejia Reza, S. (2015). Urban Mexico: the need for metropolitan governance; research report.

Anselin, L. (1995). Local Indicators of Spatial Association-LISA, Geographical Analysis, Vol.27, No.2, 93-115.

Bairoch, P. (1985). De Jericho à Mexico (Vol. 4). Gallimard.

Bannon, M.J. (1983). Urbanisation in Ireland: growth and regulation. In Blackwell, J. and Convery, F.J. (eds.). Promise and performance, Irish environmental policies analysed, Dublin: Resource and Environmental Policy Centre, University College. 261-85.

Batty M. (2018). Inventing future cities. MIT Press

Berry, B. J. (1964). Cities as systems within systems of cities. Papers in regional science, 13(1), 147-163.

Berry, B.J.L. (1968). Metropolitan area definition: a re-evaluation of concept and statistical practice. U.S. Bureau of Census, Working paper 28.

Besussi, E., Chin, N., Batty, M., \& Longley, P. (2010). The structure and form of urban settlements. In T. Rashed and C. Jürgens (eds.), Remote sensing of urban and suburban areas Remote Sensing and Digital Image Processing 10, Springer Science + Business Media B.V (pp. 13-31). DOI 10.1007/978-14020-4385-7_2

Bird, R. M., \& Slack, E. (2007). An approach to metropolitan governance and finance. Environment and Planning C: Government and Policy, 25(5), 729-755.

Borruso, G. (2003). Network density and the Delimitation of Urban Areas, Transactions in GIS, 7 (2), 177-191

Borchert, J. G. (1982). The Dutch settlement system. Acta geographica lovaniensia Louvain, 22, 207250.

Boustedt, O. (1975). Grundriss der empirischen Regionalforschung: Regionalstatistik/unter Mitarb. von Elfried Söker, sowie J. Gerhardt un HJ Bach. H. Schroedel.

Brenner N. \& Schmid C. (2014). The 'Urban Age' in Question, International Journal of Urban and Regional Research, 38(3), 735-755, DOI:10.1111/1468-2427.12115

Bretagnolle, A. (2005). Les villes dans l'espace-temps: vitesse des communications et structuration des territoires à l'échelle intra et interurbaine. in Volvey A. (ed.). Echelles et temporalités, Atlande, pp.180-187

Bretagnolle A., Delisle F., Mathian H. (2011a). Large Urban Zones (Urban Audit) specifications. Technical report for ESPON Data Base 2013.

Bretagnolle A., Guérois M., Mathian H. (2011b). Naming U.M.Z.: a database now operational for urban studies. Technical report for ESPON Data Base 2013.

Bretagnolle A., Guérois M., Le Nechet F., Mathian H., \& Pavard A. (2016). La ville à l'échelle de I'Europe: Apports du couplage et de l'expertise de bases de données issues de l'imagerie satellitale, Revue Internationale de Géomatique, vol.26, n¹, 55-78.

Bretagnolle, A., Mathian, H., Pumain, D., \& Rozenblat, C. (2000). Long-term dynamics of European towns and cities: towards a spatial model of urban growth. Cybergeo: European Journal of Geography. Brunet, R. (1989). Les villes européennes: rapport pour la DATAR, Délégation à l'Aménagement du Territoire et à l'Action Régionale. La Documentation Française.Bureau of census (1949). Metropolitan Area Data book. Washington, US Office of budget.

Burger, M. J., \& Meijers, E. J. (2016). Agglomerations and the rise of urban network externalities. Papers in Regional Science, 95(1), 5-15. 
Burian A.P. (1973). Delimitation of urban agglomerations (on the example of the Chelyabinsk agglomeration), Uchetnye zapiski Petrmskogo universiteta imeni Gorkogo, Issue 31, pp. 44-53., Perm. Canton de Genève (2019). Observatoire statistique transfrontalier, Statistiques Genève / INSEE.

Castells M. (1972). La question urbaine. François Maspero.

Cattan, N., Pumain, D., Rozenblat, C., Saint-Julien, Th. (1999). Le système des villes européennes, Anthropos $-2^{\text {nd }}$ edition, $197 \mathrm{p}$.

Champion, T. (2001). Urbanization, suburbanization, counterurbanization and reurbanization. Handbook of urban studies, 160, 1.

Champion, T. \& G. Hugo (eds.) (2004). New forms of urbanization, Ashgate, London

Chandler, T., \& Fox, G. (1974). Three Thousand Years of Urban Growth. Academic Press.

Chase-Dunn, Chr., Alvarez A., and Pasciuti D. (2005). Power and Size; urbanization and empire formation in world-systems, in C. Chase-Dunn and E.N. Anderson, eds., The Historical Evolution of World-Systems. New York: Palgrave. p. 92-112

Cheshire P., Hay D., Carbonaro G., Bevan N. (1988). Urban problems and regional policy in the European Community. European Community commission, 329 p.

Christaller, W. (1933). Die zentralen Orte in Süddeutschland: eine ökonomisch-geographische Untersuchung über die Gesetzmässigkeit der Verbreitung und Entwicklung der Siedlungen mit städtischen Funktionen. University Microfilms.

Cottineau C. (2014). DARIUS database, URL: https://figshare.com/articles/DARIUS Database/1108081

Davis, K. (1969). World urbanization 1950-1970, Volume I: basic data for cities, countries and regions. Population Monograph Series No. 4, Institute of International Studies, University of California, Berkeley, CA.

Davis, K. (1972). World urbanization 1950-1970, Volume II: analysis of trends, relationships and development. Population Monograph Series No. 9, Institute of International Studies, University of California, Berkeley, CA.

Davoudi S. (2009). City-Region. In Kitchin R, Thrift N (eds) International Encyclopedia of Human Geography, Volume 2, pp. 125-135. Oxford: Elsevier.

Dickinson R.E. (1947). City Region and Regionalism: A Geographical Introduction to Human Ecology. London: Kegan Paul, Trencher and Trubner.

Dickinson R.E. (1964). City and Region: a geographical interpretation. London - Routledge Kegan, 588 p. (see chap.12: "The city region in Western Europe" pp.336-389

Diener, R., Herzog, J., Meili, M., de Meuron, P., \& Schmid, C. (2013). Switzerland-an Urban Portrait: Vol. 1: Introduction; Vol. 2: Borders, Communes-a Brief History of the Territory; Vol. 3: Materials. Walter de Gruyter.

Dijkstra L., Poelman H. (2012). Cities in Europe. The new OECD-EC definition. Regional Focus, RF 01/2012, Regional and Urban Policy.

Dijkstra L., Poelman H. (2014). Harmonized definition of cities and rural areas: The new degree of urbanization. Working paper 1-2014. DG Regio

Dobson, J., Bright, E., Coleman, P., Durfee, R., \& Worley, B. (2000). A Global Population database for Estimating Populations at Risk. Photogrammetric Engineering \& Remote Sensing, 66(7).

Drewett R. (1967). The Definition of Standard Metropolitan Areas, London, Working paper $n^{\circ} 1, U_{r b a n}$ Growth Study PEP

Duranton, G., \& Puga, D. (2004). Micro-foundations of urban agglomeration economies. In Handbook of regional and urban economics (Vol. 4, pp. 2063-2117). Elsevier. 
EEA (2002). CORINE land cover update 2000, Technical guidelines. http://www.eea.europa.eu/ publications/technical_report_2002_89

European Commission - UN Habitat (2016). The State of European Cities Report, 2016 - Cities leading the way to a better future, European commission report, $220 \mathrm{p}$.

Faludi, A. (2015). Territorial governance challenging government. In Territorial Governance across Europe. Routledge. pp. 54-65

Feldmann, B. (2008). The Urban Audit-measuring the quality of life in European cities. Eurostat, Statistics in focus, 82.

Ferrer Regales M., Precedo Ledo A. (1982). Report on the National settlement system in Spain, Acta Geographica Lovaniensa, vol.22 pp.2-76

Freeman T.W. (1958). Geography and planning, Hutchinson university library, London, 192 p.

Fustel de Coulanges, N. D. (1866). La Cité antique : étude sur le culte, le droit, les institutions de la

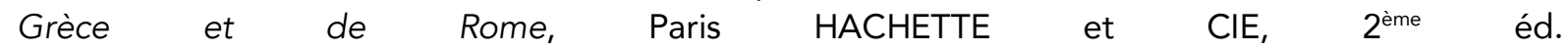
http://remacle.org/bloodwolf/livres/Fustel/intro.htm

Gallego F.J. (2010). A Population density grid of the European Union, Population and Environment, vol. 31, n6, p. 460-473.

Galster G., Hanson R., Ratcliffe M.R., Wolman H., Coleman S., Freihage J. (2001). Wrestling Sprawl to the Ground: Defining and Measuring an Elusive Concept. Housing Policy Debate, vol. 12, $n^{\circ}$ 4, p. 681 717.

Garreau, J. (1992). Edge city: Life on the new frontier. Anchor.

Geddes, P. (1915). Cities in evolution: an introduction to the town planning movement and to the study of civics. London, Norgate and Williams.

Gottmann, J. (1957). Megalopolis or the urbanization of the Northeastern seaboard. Economic geography, 33(3), 189-200.

Gottmann, J. (1961). Megalopolis: the urbanized Northeastern seaboard of the United States. Twentieth Century Fund.

Grasland, $\mathrm{Cl}$. (2010). Spatial analysis of social facts. A tentative theoretical framework derived from Tobler's first law of geography and Blau's multilevel structural theory of society. In Bavaud Fr. Mager Chr. (eds.) Handbook of Quantitative and Theoretical Geography, Faculty of the Geosciences and Environment of the University of Lausanne, pp.1-46

Guérois M. (2003). Les formes des villes européennes vues du ciel : une contribution de l'image CORINE à la comparaison morphologique des grandes villes d'Europe occidentale, doctoral Thesis, University Paris 1

Guérois, M., Bretagnolle, A., Mathian, H., \& Pavard, A. (2014). Functional Urban Areas (FUA) and European Harmonisation. A Feasibility Study from the Comparison of Two Approaches: Commuting Flows and Accessibility Isochrones. Paris: ESPON Database. In Technical report, ESPON 2013 database.

Guérois M., Bretagnolle A., Pavard A., Gourdon P. \& Zdanowska N. (2019a). Following the population of European urban areas in the last half century (1961-2011): the TRADEVE database, Cybergeo: European Journal of Geography, 891

Guérois M., Bretagnolle A., Pavard A., Gourdon P. \& Zdanowska N. (2019b). A harmonized database to follow the demographic trajectories of European cities, the TRADEVE database (Demographic Trajectories of European Cities), Cybergeo: European Journal of Geography, 892, DOI: 10.4000/cybergeo.32077

Guérois, M., \& Pumain, D. (2008). Built-Up Encroachment and the Urban Field: A Comparison of Forty European Cities. Environment and Planning A: Economy and Space, 40(9), 2186-2203. 
Halbert L., Cicille P., Rozenblat C. (2012). Quelles métropoles en Europe ? Des villes en réseau. DATAR - La documentation Française - Travaux n¹6, 108 p.

Hall P. \& Hay D. (1980). Growth Centers in the European urban system. Heineman Educational Book Hall, P. G., \& Pain, K. (Eds.) (2006). The polycentric metropolis: learning from mega-city regions in Europe. Routledge.

Hall P., Rey T., Gracey H., Drewett R. (1973). The containment of Urban England. London, Allen and Unwin LTD, $463 \mathrm{p}$.

Hanson, J. W. (2016). An Urban Geography of the Roman World, 100 BC to AD 300, (Oxford: Archaeopress).

Hanson, J., Ortman, S., Bettencourt, L., \& Mazur, L. (2019). Urban form, infrastructure and spatial organisation in the Roman Empire. Antiquity, 93(369), 702-718.

Institut national de la statistique et des études économiques (1998). Les campagnes et leurs villes, Contours et caractères, INSEE-INRA, Paris, 1998, 203 p.

Institut national de la statistique et des études économiques - INSEE (2006). Unité urbaine / Agglomération / Agglomération multicommunale / Agglomération urbaine https://www.insee.fr/fr/metadonnees/definition/c1501

Janelle, D. G. (1969). Spatial reorganization: a model and concept 1. Annals of the association of American Geographers, 59(2), 348-364.

Katsikis N. (2018). Visualizing the planetary urban, in Harrison J. \& Hoyler M., Doing Global urban research, Sage Publications, Chap.2

Lappo G. M. (1978). Development of urban agglomerations in the USSR. Moscow, Nauka.

Le Galès, P. (2016). Neoliberalism and urban change: stretching a good idea too far? Territory, Politics, Governance, 4(2), 154-172.

Lefebvre, H. (2003 [1970]) The urban revolution. Translated by Robert Bonnono, University of Minnesota Press, Minneapolis, MN.

McGee, T. G. (1991). The emergence of desakota regions in Asia: expanding a hypothesis. In NS Ginsburg, B Koppel, TG McGee. The extended metropolis: Settlement transition in Asia, University of Hawaii Press, pp.3-25

Maisonobe M., Jégou L. and Eckert D. (2018). Delineating urban agglomerations across the world: a dataset for studying the spatial distribution of academic research at city level, Cybergeo : European Journal of Geography [Online], Data Papers, document 871

Markusen, A. R., Lee, Y. S., \& DiGiovanna, S. (Eds.). (1999). Second tier cities: Rapid growth beyond the metropolis (Vol. 3). University of Minnesota Press.

Meuriot P. (1897). Des agglomérations dans l'Europe contemporaine. Essai sur les causes, les conditions, les conséquences et leurs développements, Paris Belin, 475 p.

Milego R. (2007). Urban Morphological Zones, Definition and procedural steps, Report, Copenhagen: European Environment Agency, European Topic Centre Terrestrial Environment.

Moriconi-Ebrard, F. (1994). Géopolis: pour comparer les villes du monde. Anthropos: Economica

Moriconi-Ebrard, F., \& Chatel, C. (2017). Aux frontières de l'urbain. Petites villes du monde. Territoire en mouvement, Revue de géographie et aménagement.

Moriconi-Ebrard, F., Harre D., Henrigs P. (2016). Cahiers de l'Afrique de l'Ouest : L'urbanisation des pays de l'Afrique de l'Ouest 1950-2010 Africapolis I, update 2015, OECD Publishing.

Mrad M. (2016). Intra-urban spatial organization of international functions in European Metropolises, Master Thesis, C. Rozenblat - P. Schön supervision, University of Lausanne- BBSR, 141 p.

OECD (2012). Redefining "Urban": A New Way to Measure Metropolitan Areas, OECD Publishing. 
Office of Management and Budget (OMB) (2010). Standards for Delineating Metropolitan and Micropolitan Statistical Areas; Notice, US Federal Register, June 28

Parr, J. B. (2007). Spatial definitions of the city: four perspectives. Urban Studies, 44(2), 381-392.

Pflieger, G., \& Rozenblat, C. (2010). Introduction. Urban networks and network theory: the city as the connector of multiple networks. Urban Studies, 2723-2735

Phares, D. (Ed.). (2004). Metropolitan governance without metropolitan government? Aldershot: Ashgate.

Polyan P. M. (1980). Urbanization and territorial-urban structures. Territorial socio-economic systems of Ural, Perm, pp. 80-86

Polyan P., Selivanova T. (2007). Urban Agglomerations of Russia and New Tendencies of Evolution of their Networks. Izvestia RAN. Seriya geograficheskaya, N 5, p. 18-27.

Pumain, D., Paulus, F., Vacchiani-Marcuzzo, C., \& Lobo, J. (2006). An evolutionary theory for interpreting urban scaling laws. Cybergeo: European Journal of Geography.

Pumain, D., \& Rozenblat, C. (2018). Introduction: A global view of urbanization. In Rozenblat C., Pumain D., Velasquez E. (eds.) International and Transnational Perspectives on Urban Systems, UNHabitat / Springer - Series: Advances in Geographical and Environmental Sciences, IX-XVIII.

Pumain D., Saint-Julien Th., Cattan N., Rozenblat C. (1992). The concept of city in Europe, Eurostat Luxemburg, NUREC, $54 \mathrm{p}$.

Pumain D., Swerts E., Cottineau C, Vacchiani-Marcuzzo C., Ignazzi C.A., Bretagnolle A., Delisle Fr., Cura R., Lizzi L. et Baffi S. (2015). Multilevel comparison of large urban systems, Cybergeo : European Journal of Geography, 706

Robinson, J., \& Roy, A. (2016). Debate on global urbanisms and the nature of urban theory. International Journal of Urban and Regional Research, 40(1), 181-186,

Rogov, M., \& Rozenblat, C. (2018). Urban resilience discourse analysis: towards a multi-level approach to cities. Sustainability, 10(12), 4431.

Rogov, M., \& Rozenblat, C. (2020). Globalization of Russian Cities: Towards a Construction of Large Urban Regions, Cybergeo

Rozenblat C. (2000). Statistics and Maps, in Koolhaas R., Boeri S., Kwinter S., \& Tazi N, Mutations: Harvard project on the city. Arc-en-Rêve / Actar, Barcelona.

Rozenblat, C. (2009). European urban polycentrism: a multiscale typology. Geographica Helvetica, 64(3), 175-185.

Rozenblat, C. (2010). Opening the black box of agglomeration economies for measuring cities' competitiveness through international firm networks. Urban Studies, 47(13), 2841-2865.

Rozenblat C. (2018). Chapter 1.2: Reconfiguration of the worldwide Urban system through transnational networks, in Rozenblat C., Pumain D., Velasquez E. (eds.). International and Transnational Perspectives on Urban Systems, UN-Habitat / Springer-Nature Series "Advances in Geographical and Environmental Sciences"

Rozenblat C., Bellwald A., (2013). Paris in the flow of multinational firms, Report for the Institute of planning-PARIS (IAU)

Rozenblat C., Bellwald A., Gomez P. (2015). Chapitre 3: L'international est l'affaire de toute la métropole, in Fouchier V. Frachon N., 06-Interpellation stratégique Internationalisation: I'affirmation euroméditerranéenne et mondiale d'Aix-Marseille-Provence, Mission interministérielle pour le projet métropolitain Aix-Marseille-Provence, pp.35-48

Rozenblat, C., \& Pumain, D. (2018). Conclusion: Toward a methodology for multi-scalar urban system policies. International and Transnational Perspectives on Urban Systems, in Rozenblat C., Pumain D., Velasquez E. (eds.) (2018). International and Transnational Perspectives on Urban Systems, UN-Habitat / Springer - Series: Advances in Geographical and Environmental Sciences, pp.385-393 
Rozenblat C., Pumain D., Velasquez E. (eds.) (2018). International and Transnational Perspectives on Urban Systems, UN-Habitat / Springer - Series: Advances in Geographical and Environmental Sciences. Salom, J. \& Albertos, J.M. (2010). Densidad de la red viaria y forma urbana: Delimitación del espacio urbano en ocho aglomeraciones españolas. En Feria Toribio, J.M. y Albertos Puebla, J.M.: La ciudad metropolitana en España: Procesos urbanos en los inicios del siglo XXI, Thomson Reuters, Pamplona, 49-94

Satterthwaite, D. (2010). Urban myths and the mis-use of data that underpin them (No. 2010/28). WIDER Working Paper.

Scott, A. J. (2019). City-regions reconsidered. Environment and Planning A: Economy and Space, 51(3), 554-580.

Scott, A. J., \& Storper, M. (2015). The nature of cities: the scope and limits of urban theory. International journal of urban and regional research, 39(1), 1-15.

Sforzi F. (1989). I mercati locali del lavoro in Italia, Istat, I. R. P. E. T. Milano.

Sorensen, A., \& Okata, J. (Eds.). (2010). Megacities: Urban form, governance, and sustainability (Vol. 10). Springer Science \& Business Media.

Statistical Office of the United Nations \& Department of Social Affairs (1949). Demographic Yearbook, United Nations - New York 592 p.

Statistical Office of the United Nations \& Department of Economic Affairs (1952). Demographic Yearbook, United Nations - New York 524 p.

Storper, M., \& Scott, A. J. (2016). Current debates in urban theory: A critical assessment. Urban studies, Vol 53, Issue 6, 1114-1136.

Storper, M., \& Venables, A. J. (2004). Buzz: face-to-face contact and the urban economy. Journal of economic geography, 4(4), 351-370.

Swerts E., Liao L. (2018). The Chinese Urban System: Political Evolution and Economic Transition, in in Rozenblat C., Pumain D., Velasquez E. (eds.) (2018). International and Transnational Perspectives on Urban Systems, UN-Habitat / Springer - Series: Advances in Geographical and Environmental Sciences, pp.215-235

Tannier, C. Thomas I., Vuidel G., Frankhauser P. (2011). A Fractal Approach to Identifying Urban Boundaries, Geographical Analysis, 43, 211-227

Terrier, C. (1980). Réalité des régions françaises. INSEE

Tiebout, C. M., \& Houston, D. B. (1962). Metropolitan finance reconsidered: budget functions and multi-level governments. The Review of Economics and Statistics, 412-417.

Torre, A., \& Gallaud, D. (2020). Handbook on proximity, Edward Elgar (in press).

United Nations (2007). 2007 world population data sheet. Population Reference Bureau.

United Nations, Department of Economic and Social Affairs, Population Division (2018). World Urbanization Prospects: The 2018 Revision, Methodology. Working Paper No. ESA/P/WP.252. New York: United Nations.

United Nations - Habitat (2016). World Cities Report 2016: Urbanization and Development -

Emerging Futures, UN-Habitat, $262 \mathrm{p}$

Van den Berg, L., Drewett, R., Klaassen, L. H., Rossi, A., \& VljVERBERG, C. H. (1982). A study of growth and decline (Vol. 1). Oxford: Pergamon Press.

Wu, F. (2016). China's emergent city-region governance: a new form of state spatial selectivity through state-orchestrated rescaling. International Journal of Urban and Regional Research, 40(6), 1134-1151.

Zubarevich N.V. (2019). Spatial Development Strategy: Priorities and instruments. Voprosy Ekonomiki. 2019. No 1, pp. 135-145. DOI: https://doi.org/10.32609/0042-8736-2019-1-135-145 